\title{
Bacterial dynamics during the transition from spring bloom to oligotrophy in the northwestern Mediterranean Sea: relationships with particulate detritus and dissolved organic matter
}

\author{
France Van Wambeke ${ }^{1, *}$, Madeleine Goutx ${ }^{1}$, Laurent Striby $^{1}$, Richard Sempéré ${ }^{1}$, \\ Francesca Vidussi ${ }^{2}$
}

\author{
${ }^{1}$ Microbiologie Marine, CNRS, UMR 6117, Campus de Luminy, Case 907, 13288 Marseille Cedex 9, France \\ ${ }^{2}$ Observatoire Océanologique de Villefranche, Laboratoire de Physique et Chimie Marines, URA CNRS 2076, \\ BP 08, 06238 Villefranche-sur-Mer, France
}

\begin{abstract}
The variability in microbial communities (abundance and biomass), bacterial production and ectoaminopeptidase activity, particulate and dissolved organic carbon (POC, DOC), and particulate and dissolved lipids was examined in spring 1995 in the northwestern Mediterranean, where a transition from the end of a bloom to pre-oligotrophic conditions was observed. Four time series of $36 \mathrm{~h}$ each and $4 \mathrm{~h}$ sampling intervals were performed at $5 \mathrm{~m}$ and at the chlorophyll maximum $(30 \mathrm{~m})$ between 11 and 31 May. Simultaneous measurements of pigments, abundance of hetero- and autotrophic flagellates, bacteria and POC enabled the estimation of living POC (defined as autotrophic- $\mathrm{C}$ plus heterotrophic-C biomass), and thus the detrital organic carbon. During the first 2 time series (11 to 15 May), the bacterial-C biomass was higher than the autotrophic-C biomass at $5 \mathrm{~m}$ (ratio 1.4 and 1.7), whereas the opposite trend was observed in the chlorophyll peak (ratio 0.7 for the first cycle). However, at the end of May, autotrophic-C biomass was equivalent to bacterial-C biomass at both depths studied. The detrital pool remained a more or less constant fraction of the POC (52, 53 and 47\% on 11-12 May, 14-15 May and 30-31 May) at the chlorophyll peak, whereas it decreased significantly with time (62 to $53 \%$ ) at $5 \mathrm{~m}$. Relationships between bacterial activities and evolution of available resources were not systematically evidenced from our $36 \mathrm{~h}$ diel cycle data. Nevertheless, at the monthly scale, comparison of bacterial carbon demand (BCD) to potential carbon resources (detrital POC and DOC) showed that bacteria fed differently on the various pools. From ectoaminopeptidase turnover rates and detrital POC, the potential hydrolysis rate of detritus was calculated. Depending on the choice of conversion factors for bacterial production and estimates of hydrolysis turnover rates, it was shown that bacterial hydrolysis of detritus could be one of the DOC accumulation sources. We observed that the percentage of BCD supplied by detrital POC hydrolysis increased in the surface and decreased in the chlorophyll peak. An index of lipid degradation in POC, the lipolysis index, increased during the month at $5 \mathrm{~m}$, also indicating a higher hydrolysis of POC. The opposite trend was observed in the chlorophyll maximum layer. The selective decrease in dissolved lipids in DOC in the chlorophyll maximum layer, particularly free fatty acids, also suggests that bacteria utilized increased fractions of carbon sources from the DOC. We concluded that partitioning between DOC and detritus as resources for bacteria can change during the rapid transition period from mesotrophy to oligotrophy in the northwestern Mediterranean.
\end{abstract}

KEY WORDS: Particulate detritus - Ectoaminopeptidase activity · Bacterial production · Lipids · Pigments $\cdot$ Northwestern Mediterranean 


\section{INTRODUCTION}

The flux of carbon channelled through bacteria, i.e. the bacterial carbon demand (BCD), is calculated as the ratio of bacterial production to bacterial growth efficiency. Bacterial production is presently a commonly measured parameter (Ducklow \& Carlson 1992). By the use of biodegradation experiments or respiration rates, increasing data on bacterial growth efficiencies on a wide range of trophic conditions are available (del Giorgio \& Cole 1998). However, it is still difficult to estimate which carbon sources are used by bacteria, both in terms of origin and nature. Not only living particles provide dissolved organic carbon (DOC) from egestion, excretion and sloppy feeding processes (Jumars et al. 1989); detrital particles also provide DOC from bacterial ectoenzymatic hydrolysis and solubilisation processes (Smith et al. 1992, Sempéré et al. 2000). Numerous studies reveal the importance of ectoenzymatic activities in fueling DOC from particles and degrading dissolved polymeric material into an assimilable form (Hoppe et al. 1988, 1993, Chrost 1991, Middleboe et al. 1995). The contribution of a given chemical pool to BCD can be assessed by using chemical analysis of dissolved organic matter combined with radiolabelling techniques, for example carbohydrates (Skoog et al. 1999), and free and combined amino acids (Hagström et al. 1984, Keil \& Kirchman 1999). However, the chemical characterization of the whole DOC pool is far from known (Benner et al. 1992, McCarthy et al. 1996).

In addition, quality and quantity of carbon resources available for bacteria (Carlucci et al. 1984, Jørgensen 1987, Gasol et al. 1998) exhibit short-term variations due to various processes. On a short time scale, autotrophs have to change their metabolism with diel variations in light availability, and migrating organisms preying at night in surface waters modify the intensities of grazing and sloppy feeding. As a consequence, bacteria respond quickly to spatial and temporal variations in their environment by adapting their metabolism, like production (Zohary \& Robarts 1992, Christaki et al. 1996, Gasol et al. 1998), ectoenzymatic activity (Middelboe \& Søndergaard 1993, Bochandsky et al. 1995), and utilization of molecules (Carlucci et al. 1984, Jørgensen 1987). On a seasonal scale, DOC accumulates in surface waters of the Mediterranean Sea during the stratification period (Copin-Montégut \& Avril 1993). Such accumulation allows transfer of organic material to the deep layers through diffusive processes and winter convection of DOC. Thus, determining to which extent bacteria will utilize suspended detrital particles rather than the one and only DOC pool is particularly important to the fate of organic carbon from the euphotic zone.
In May 1995, in the framework of France-JGOFS program, we examined bacterial processes during a multi-disciplinary cruise (the DYNAPROC cruise) studying physical, chemical and biological fluxes simultaneously at a high sampling frequency in the upper layers of the Mediterranean time series station Dyfamed (Andersen \& Prieur 2000). Reduced physical dynamics characterize this station, situated in the central part of the Ligurian Sea and generally out of the influence of the Ligurian Current. This station can be considered as typical of the whole northwestern Mediterranean Sea (Marty et al. 1994). Previous results indicated that transfer of organic material to deep layers takes place through diffusive processes and winter convection of DOC (18.4 $\mathrm{g} \mathrm{C} \mathrm{m}^{-2} \mathrm{yr}^{-1}$, Copin-Montégut \& Avril 1993) and from export of large sinking particles (5 $\mathrm{g} \mathrm{C} \mathrm{m}^{-2} \mathrm{yr}^{-1}$, Miquel et al. 1994).

In the frame of this program, our goal was to determine whether there were significant variations concerning potential carbon resources (DOC, particulate detritus), whether bacteria modified their activities according to the structure of the microbial food web and the available organic matter, and on what time scale could we observe such variations. For this, we recorded estimations of bacterial production, ectoaminopeptidase activity and microbial biomasses (bacteria, flagellates, pigments), particulate organic carbon (POC) and DOC at high frequency in the water column. Simultaneously, the lipid composition in POC and DOC pools, which indicated the degree of degradation of particles and DOC, was examined. We examined variations of these parameters on daily and weekly scales. To our knowledge, there is no direct way to determine the particulate detritus fraction in POC. Thus, we developed an approach combining distribution of diagnostic pigment, and epifluorescence counts of $<20 \mu \mathrm{m}$ living components to accurately determine auto- and heterotrophic carbon biomass. Concentration of particulate detritus were then obtained by the difference between POC and living biomass. BCD was compared to potential hydrolysis of particulate detritus. This allowed us to relate the variability of bacterial properties on the diel and month scale to the characteristics of organic matter and the structure of the microbial food web.

\section{MATERIALS AND METHODS}

Sampling. Hydrological, chemical and biological parameters were recorded in the water column at the Dyfamed station $\left(43^{\circ} 25^{\prime} \mathrm{N}, 07^{\circ} 52^{\prime} \mathrm{E}, 2350 \mathrm{~m}\right.$ depth) following the drift of sediment traps during 4 cycles of 36 h each (C1: 11-12 May, C2: 14-15 May, C3: 27-28 May, C4: 30-31 May, 1995). Time-series observations 
were assembled from serial hydrocasts through the upper $500 \mathrm{~m}$ made precisely every $4 \mathrm{~h}$, from 10:00 $\mathrm{h}$ the first day until 22:00 $\mathrm{h}$ the second day (UT+2). Sunrise and sunset were, respectively, at 06:30 and 21:10 h $(\mathrm{UT}+2)$ during the cruise. Samples were collected using Niskin bottles at 2 depths: $5 \mathrm{~m}$ because the surface reference layer was assumed to be influenced by meteorological events (wind stress, rain) and because this is the layer where maximum light intensity occurs (50\% incident light), and $30 \mathrm{~m}$ because this layer corresponded to the depth of the chlorophyll maximum established since the beginning of the cruise (3\% incident light). Aliquots were taken immediately after recovery of water samples for measurements of biological and chemical parameters. The biological variables measured included the numbers of bacteria, cyanobacteria, phototrophic and heterotrophic nanoflagellates, bacterial production and ectoaminopeptidase activity. Biochemical variables were POC and DOC, particulate (PL) and dissolved (DL) lipids (DOC and DL were sampled every $4 \mathrm{~h}$ only for $\mathrm{C} 1$ and $\mathrm{C} 3$ ), and pigments. Whenever possible (twice during $\mathrm{C} 1$ and $\mathrm{C} 2$, and once during $\mathrm{C} 3$ and $\mathrm{C} 4$ ), bacterial activities and abundance of microbial populations were estimated along vertical profiles between 0 and $200 \mathrm{~m}$ depth.

Biochemical analyses. Pigments were analyzed by High Performance Liquid Chromatography (HPLC) and used herein to derive the concentration (in terms of chlorophyll a) of different phytoplanktonic groups (Claustre et al. 1994) and, in a second step, to convert them in terms of autotrophic carbon biomass. The chemo-taxonomic significance of the main diagnostic pigments is as follows: peridinin is the marker of dinoflagellates, 19'-hexanoyloxyfucoxanthin $+19^{\prime}$-butanoyloxyfucoxanthin (19' HF + 19' BF) of chromophyte nanoflagellates, alloxanthin of cryptophytes, fucoxanthin of diatoms, zeaxanthin of cyanobacteria, chlorophyll $b$ of green flagellates, divinyl-chlorophyll $a$ (Dv-chl a) of prochlorophytes. Detailed protocols of pigment sampling and analysis during the DYNAPROC cruise are available in Vidussi et al. (2000).

For POC and PL analysis, 4 and 21 samples, respectively, were filtered onto pre-combusted $\left(450^{\circ} \mathrm{C}, 6 \mathrm{~h}\right)$ $\mathrm{GF} / \mathrm{F}$ glass fiber filters. POC was determined using a LECO CHN 900 analyzer. Coefficient of variation (CV) inter-filter was within 2 to $10 \%$. Particulate lipids were extracted from the filters according to the Bligh \& Dyer (1959) protocol. Briefly, PLs were dissolved in a monophasic mixture of dichloromethane:methanol:water (1.25:1:0.8). Then, addition of water (final proportion $2: 2: 1.8)$ separated the mixture into aqueous and organic phases. Lipids were concentrated in the latter. Dissolved lipids were liquid-liquid extracted from the GF/F filtrate (2 l) by dichloromethane. From the particulate and dissolved extracts, lipid classes were sepa- rated on chromarods and quantified on a thin layer chromatography/flame ionisation detection Iatroscan TH10-MKIV apparatus according to Goutx et al. (1990) modified by Striby et al. (1999). The compounds detected included reserve lipids (TG: triglycerides, and WE: wax esters), membrane lipids (ML), degradation metabolites of these acyl-lipids, namely free fatty acids (FFA), alcohols (ALC), diglycerides (DG) and monoglycerides (MG), and hydrocarbons. CV for particulate and dissolved lipids analysis was under 11 and $16 \%$, respectively. In the present paper, we use the following information for characterizing the carbon pools and the degradation status of organic matter: total lipids (the sum of the different classes in dissolved fraction, DL, and in particulate fraction, PL, from which we subtracted hydrocarbons), triglycerides (TG), and the ratio of degradation metabolites to the entire acyl-lipids $(\mathrm{FFA}+\mathrm{ALC}+\mathrm{DG}+\mathrm{MG}) /(\mathrm{TG}+\mathrm{WE}+\mathrm{ML})$. This ratio (the lipolysis index) was determined in dissolved and particulate phases, respectively LId and LIp. Carbon equivalents were estimated from the respective distribution of each lipid class.

Samples for DOC analysis were measured by high temperature combustion on a Shimadzu TOC 5000 Analyzer. Details of this procedure have been previously described (Dafner et al. 1999, Yoro et al. 1999). A 4-point calibration curve was performed daily with standards (83 to $332 \mu \mathrm{M}$ C) prepared by diluting a stock solution of potassium hydrogen phthalate in Milli-Q water. The instrument blank ranged from 6 to $9 \mu \mathrm{M} \mathrm{C}$ and the error between 2 duplicate samples ranged from 3 to $10 \%$.

Bacteria, cyanobacteria, nanoflagellates: epifluorescence countings. Samples for the enumeration of bacteria and protozoa were fixed with $2 \%$ buffered formalin filtered through $0.2 \mu \mathrm{m}$. Between 6 and $15 \mathrm{ml}$ were filtered within $12 \mathrm{~h}$ after sampling on black Nuclepore filters $(0.2 \mu \mathrm{m})$ that were subsequently stained with DAPI (4,6-diamidino-2-phenylindole, final concentration $2500 \mathrm{\mu g} \mathrm{l}^{-1}$ ). Filters were mounted in Olympus immersion oil on slides and stored frozen until examination. On the same filter, we counted bacteria by image-analyzed epifluorescence microscopy (Van Wambeke 1995), and cyanobacteria (CYAN), heterotrophic nanoflagellates (HNAN), and phototrophic nanoflagellates (PNAN) by manual epifluorescence microscopy. For bacteria, up to 40 fields containing 50 to 80 bacteria each were counted (CV inter-field, 6 to $16 \%$ ). CYAN were counted under blue light excitation. About 60 to 100 flagellates were counted per filter in random $10 \mathrm{~mm}$ strips ( $80 \mu \mathrm{m}$ width). CV inter-strips were within 10 to $22 \%$. HNAN were classified as all eucaryotic non-pigmented organisms less than $10 \mu \mathrm{m}$ in size, and PNAN were identified as chlorophyll containing cells by their red autofluorescence. 
Bacterial biomass (BB) was calculated from abundances using $20 \mathrm{fg} \mathrm{C}^{\mathrm{C}}$ cell $^{-1}$ (Lee \& Fuhrman 1987). CYAN were dominated by coccoid forms with diameters ranging from 0.8 to $1.2 \mu \mathrm{m}$ with a mean diameter of $0.9 \pm 0.2 \mu \mathrm{m}$, and thus a mean biovolume of $0.45 \mu^{3}$ was used. Size spectra of nanoflagellates was established on some occasions from which we calculated an average biovolume of $6 \mu^{3}$ for HNAN and of $38 \mu \mathrm{m}^{3}$ for PNAN. Biovolume-carbon conversion factors were

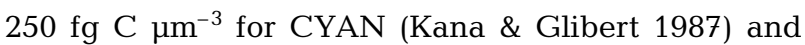
$220 \mathrm{fg} \mathrm{C} \mathrm{\mu m}^{-3}$ for HNAN and PNAN (Børsheim \& Bratbak 1987).

Pigment-derived autotrophic biomass. The autotrophic carbon biomass was estimated by the chlorophyll a (chl a) content of the different taxonomic phytoplankton groups, taking into account the effect of photoacclimation on the chl a to carbon ratio for each category of phytoplankton.

The chl a concentration associated to each phytoplanktonic group was derived from pigment data using multiple regression analysis which calculates the ratio between chl $a$ and the specific pigment for the different phytoplankton group. This approach was used and described in details in Vidussi et al. (2000) although in this latter paper, the empirical regression equation was realized on depth-integrated (0 to $200 \mathrm{~m}$ ) diagnostic pigments.

The multiple regression equation is:

$[\mathrm{T} \operatorname{chl} a]=[\mathrm{chl} a+\operatorname{Dv} \operatorname{chl} a]=y$ intercept $+a\left[19^{\prime}-\right.$ $\left.\mathrm{HF}+19^{\prime}-\mathrm{BF}\right]+b$ [fucoxanthin $]+c$ [zeaxanthin $]+d$ [alloxanthin $]+e[\mathrm{chl} b]+f$ [peridin $]+[\mathrm{Dv}$ chl $a]$

in which the terms in brackets are the concentration of pigments in $\mathrm{ng} \mathrm{l}^{-1}, \mathrm{~T} \operatorname{chl} a$ is the total $\mathrm{chl} a$, and the

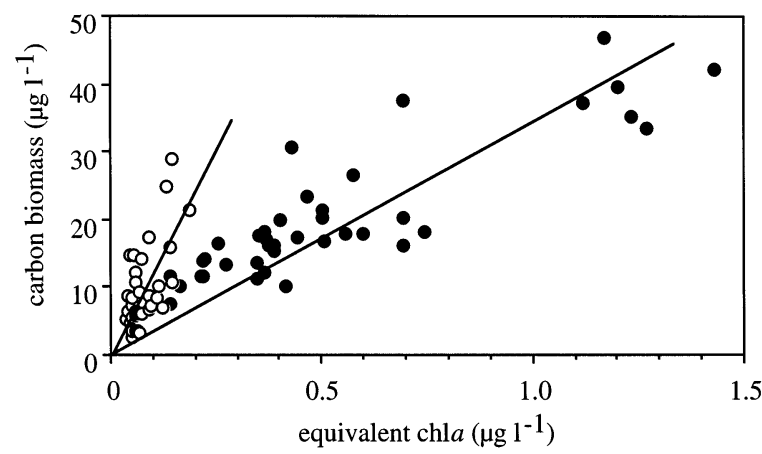

Fig. 1. Relationships between carbon biomass of phototrophic nanoflagellates (calculated from epifluorescence counts and biovolume) and equivalent chl a concentrations of their corresponding phytoplankton groups (calculated from the 4 families of pigments: 19' $\mathrm{HF}, 19^{\prime} \mathrm{BF}$, alloxanthin and chlorophyll $b$, and their respective diagnostic pigment/chl $a$ ratios) at 5 (O) and $30 \mathrm{~m}$ depth $(\bullet)$. Regression equations are forced to cross the origin. Slope $=118 \pm 9, \mathrm{df}=35, \mathrm{r}^{2}=0.402$ at $5 \mathrm{~m}$ and slope $=34.6 \pm 1.5, \mathrm{df}=38, \mathrm{r}^{2}=0.63$ at $30 \mathrm{~m}$
Table 1. Results of the multiple regression of diagnostic pigment concentrations with chl a. Regressions tested with an integrated pigment concentration ( 0 to $200 \mathrm{~m}$, Vidussi et al. 2000), with $5 \mathrm{~m}$ data or with $30 \mathrm{~m}$ data (this study). Chl a, diagnostic pigments and chl a unexplained are expressed in $\mathrm{ng} \mathrm{l}^{-1}$ in regressions made on pigments from 5 and $30 \mathrm{~m}$ and in $\mathrm{mg}$ $\mathrm{m}^{-2}$ for regression made on integrated pigments. Constant values were imposed for alloxanthin (3.34), chl $b(0.70)$ and peridinin (2.50) in the 3 regressions tested. The chl a unexplained by the regression model is the $y$ intercept of the regression. $\mathrm{r}^{2}=0.900, \mathrm{df}=41$ at $5 \mathrm{~m}$ and $\mathrm{r}^{2}=0.947, \mathrm{df}=42$ at $30 \mathrm{~m}$

\begin{tabular}{|lccc|}
\hline & Integrated & $5 \mathrm{~m}$ & $30 \mathrm{~m}$ \\
\hline Chl a unexplained & 3.82 & $21 \pm 15$ & $125 \pm 41$ \\
Chl a/(19' HF + 19' $\mathrm{BF})$ & 0.68 & $0.58 \pm 0.22$ & $0.65 \pm 0.05$ \\
Chl a/fucoxanthin & 1.07 & $2.47 \pm 0.58$ & $1.03 \pm 0.29$ \\
Chl a/zeaxanthin & 1.32 & $1.29 \pm 0.29$ & $1.07 \pm 0.17$ \\
\hline
\end{tabular}

terms a to $f$ refer to the chl $a$ /specific pigment ratio of the respective phytoplankton groups; $d$, e and $f$ were imposed as constant values from the literature (Vidussi et al. 2000), whereas values $a, b, c$ resulted from running the regression equation.

Since photoacclimation can result in both changes in chl $a$ /specific pigment ratios and in the $\mathrm{C} / \mathrm{chl} a$ ratio for each phytoplankton group (Cullen 1982), we estimated for each depth (5 and $30 \mathrm{~m}$ ), an equivalent chl a for each category of diagnostic pigment using multiple regression analysis. Therefore, taking into account the photoacclimation process, we realized the multiple regression analysis on 2 data sets: diagnostic pigments at $5 \mathrm{~m}$ depth and diagnostic pigments at $30 \mathrm{~m}$ depth. Results of multiple regression analysis are presented in Table 1. No significant difference between the coefficients were obtained from regression using depthintegrated pigments reported by Vidussi et al. (2000) and those calculated from pigment concentrations at 5 and $30 \mathrm{~m}$ depth (this study), except for fucoxanthin at $5 \mathrm{~m}$.

More effects of photoacclimation of phytoplankton species to irradiance were expected in the $\mathrm{C} / \mathrm{chl} a$ ratios. We calculated depth-dependant $\mathrm{C} / \mathrm{chl}$ a conversion factors for 5 and $30 \mathrm{~m}$ by comparison of PNAN carbon (obtained from epifluorescence) and diagnostic pigments. We assumed the 3 phytoplankton groups: chromophyte nanoflagellates (identified by $19^{\prime} \mathrm{HF}+$ $19^{\prime}$ BF) + cryptophytes (identified by alloxanthin) + green flagellates (identified by chl $b$ ) to be representative of PNAN. We plotted the biovolume-based PNAN carbon biomass (see section above) against the sum of equivalent chl a concentration obtained from these 4 groups of pigments (Fig. 1) at 5 and $30 \mathrm{~m} \mathrm{depth,}$ respectively. Both correlations were significant $(\mathrm{p}<$ 0.01 ). The slopes 120 and 35 were representative of the $\mathrm{C} / \mathrm{chl}$ a ratio of chromophyte nanoflagellates, crypto- 
Table 2 . C/chl a ratios in phytoplankton species: average values reported in the literature, and estimated values at 5 and $30 \mathrm{~m}$ depth

\begin{tabular}{|lccc|}
\hline & Literature data & $5 \mathrm{~m}$ & $30 \mathrm{~m}$ \\
\hline Nanoflagellates $^{\mathrm{a}}$ & 80 & 120 & 35 \\
Cryptophytes $^{\mathrm{a}}$ & 80 & 120 & 35 \\
Green algae $^{\mathrm{a}}$ & 80 & 120 & 35 \\
Dinoflagellates $^{\mathrm{b}}$ & 200 & 300 & 86 \\
Diatoms $^{\mathrm{b}}$ & 30 & 45 & 13 \\
Cyanobacteria $^{\mathrm{b}}$ & 80 & 120 & 35 \\
Prochlorophytes $^{\mathrm{b}}$ & 80 & 120 & 35 \\
${ }^{\text {aFor nanoflagellates, cryptophytes and green algae, ratios }}$ \\
are those obtained from Fig. 1 & & \\
${ }^{b}$ For the other groups, averages values of ratios C/chl a \\
were taken from the literature and adjusted for 5 and \\
30 m depth in order to respect the 3.5-fold ratio (due to \\
photoacclimation) obtained for nanoflagellates \\
\hline \multicolumn{4}{l}{} \\
\hline
\end{tabular}

phytes and green nanoflagellates at 5 and $30 \mathrm{~m}$, respectively. The ratio of the slopes (120 and 35) differed by a factor of 3.5. Accordingly, we used different $\mathrm{C} / \mathrm{chl} a$ ratios at 5 and $30 \mathrm{~m}$, differing by this factor of 3.5, for other taxonomic phytoplankton groups (Table 2), with respect to the range described in the literature (Durbin 1977, Claustre \& Gostan 1987, Kana \& Glibert 1987, Claustre et al. 1994, Vidussi 1998).

Bacterial production. Bacterial production (BP) was estimated by the thymidine method (Fuhrman \& Azam 1982). Duplicate samples (20 to $40 \mathrm{ml}$ ) and a blank (formalin-killed, $2 \%$ final concentration) were incubated with $20 \mathrm{nM}$ [Methyl- ${ }^{3} \mathrm{H}$ ]-thymidine $\left({ }^{3} \mathrm{H}-\mathrm{Tdr}, 44 \mathrm{Ci}\right.$ $\mathrm{mmol}^{-1}$ ) for 2 to $4 \mathrm{~h}$ in sterile disposable plastic flasks at $15^{\circ} \mathrm{C}$. Incubation was terminated with the addition of $2 \%$ formalin. Samples were filtered through $0.2 \mu \mathrm{m}$ Nuclepore filters, extracted with ice cold $5 \%$ trichloracetic acid (TCA) for 15 min, and finally rinsed 3 times with $5 \%$ TCA. We preliminarily checked the conditions for linear incorporation and isotope saturation. We used the commonly cited conversion factor of $2 \times$ $10^{18}$ cells $\mathrm{mol}^{-1}$ thymidine incorporated as well as an average $\left(0.84 \times 10^{18} \mathrm{cells} \mathrm{mol}^{-1}\right)$ of empirical factors reported for the western Mediterranean Sea by Fernández et al. (1994), Christaki \& Van Wambeke (1995), Gasol et al. (1998) and from experiments on biodegradation of DOC conducted in April 1995 in the area (Sempéré et al. 1998).

Ectoaminopeptidase activity. Hydrolysis of fluorogenic substrate was used to measure ectoaminopeptidase activity. The fluorescent analog L-leucine-4methyl-7-coumarinylamide (MCA-leu) was added to $30 \mathrm{ml}$ of water ( $1 \mu \mathrm{M}$ final concentration) in sterile disposable plastic tubes and incubated for up to $5 \mathrm{~h}$. During the incubation, subsamples were transferred to the quartz cuvette and fluorescence (excitation $365 \mathrm{~nm}$, emission $445 \mathrm{~nm}$ ) was read with a Kontron SFM 23B spectrofluorometer calibrated with MCA. Blanks consisted of $0.2 \mu \mathrm{m}$ filtered seawater which was boiled for 15 min. MCA-leu hydrolysis rates were calculated by subtracting the rate of change in fluorescence of the blanks from the average rate of change in fluorescence of the duplicates. Mean reproducibility within duplicates was $3 \%$ and rate of blanks ranged from 0.5 to $4 \%$ of the mean response of duplicates. Activity was expressed in terms of fraction of the substrate hydrolyzed per hour (ectoaminopeptidase turnover rate [Hr], in \% $\mathrm{h}^{-1}$ ), as defined by Hoppe et al. (1988).

Statistical data treatment. A long-term trend was determined by linear regression of parameters with time and an F-test on slopes were performed. The depth of the chlorophyll peak did not always correspond to the $30 \mathrm{~m}$ depth. Thus, for the study of the long-term trend at $30 \mathrm{~m}$ depth, we selected only the data coinciding with the chlorophyll peak.

For estimating diel variability, day samples (10:00, 14:00, 18:00 h UT+2) were compared to night samples $(22: 00,02: 00,06: 00 \mathrm{~h} \mathrm{UT}+2)$ and the significance of variations were tested using a Student's $t$-test after verification of homogeneity of variances. To be able to perform this test, we normalized the data. They were thus expressed in terms of percentage of the $36 \mathrm{~h}$ time series means when no trend with time was present, and divided by the fit to the tendency when a $36 \mathrm{~h}$ trend was significant.

\section{RESULTS}

\section{Hydrodynamic and biological characteristics during the period of study}

A period of calm characterized the first cycle (11-12 May). Until 13 May, the wind was low (less than $6 \mathrm{~m} \mathrm{~s}^{-1}$ ) and the cloud cover particularly weak before 10 May, resulting in a regular warming of the water mass (+185 $\mathrm{W} \mathrm{m}^{-2}$ for the layer 0 to $30 \mathrm{~m}$ ), which led to the stratification and phytoplankton development (Andersen \& Prieur 2000). A bloom termination was depicted (Fig. 2) around 11 of May, characterized by a narrow and high chl a peak (1.75 $\mathrm{mg} \mathrm{m}^{-3}$ ) and high primary production (Vidussi et al. 2000). On 13 May, a wind event occurred (up to $16 \mathrm{~m} \mathrm{~s}^{-1}$ ), just between $\mathrm{C} 1$ (11-12 May) and C2 (14-15 May) inducing the rising of isopycnals towards the surface and nutrient increase in the surface water. The in vivo fluorescence peak moved up from 30 to $20 \mathrm{~m}$ depth. Precipitation occurred between 11 and 12 May. During the end of the cruise, the cloud cover was maintained and generally, the wind speed was low $\left(<8 \mathrm{~m} \mathrm{~s}^{-1}\right)$, except during 24-25 May, when winds higher than $10 \mathrm{~m} \mathrm{~s}^{-1}$ were 
a) Potential temperature $\left({ }^{\circ} \mathrm{C}\right)$

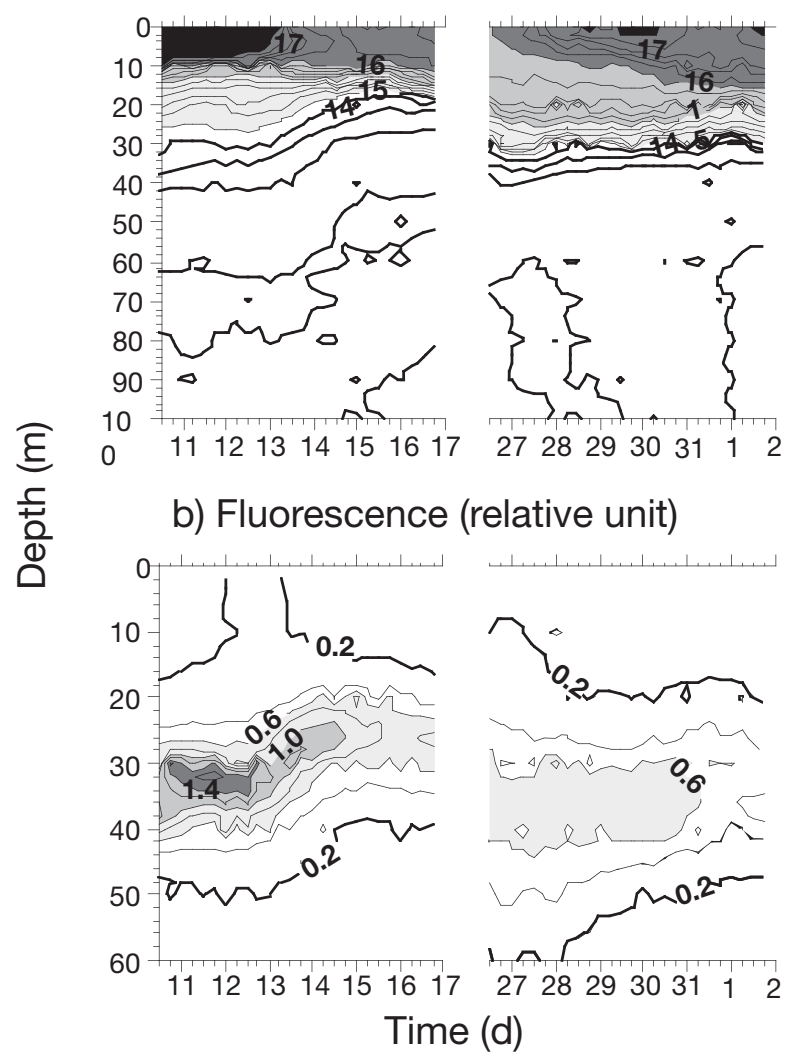

Fig. 2. Temporal variation of (a) temperature and (b) in situ fluorescence at the sampling site during the 2 periods studied: 10-17 May and 26 May-2 June, 1995 (after Andersen \& Prieur 2000)

observed. After May 27, the warming up of surface layers was observed again and the depth of the thermocline was constant.

The succession of the phytoplankton communities described by using diagnostic pigment (Vidussi et al. 2000) was as follows. At the termination of the bloom, chromophyte nanoflagellates (mainly Prymnesiophytes) dominated the phytoplankton biomass (26 to $50 \%$ ) except during the first wind event where diatoms (the other dominant group) became predominant within $24 \mathrm{~h}$. Grazing accompanied by faecal pellet production by herbivorous zooplankton largely controlled the particle flux (Goutx et al. 2000). During the second part of the observations (27 to 31 May), the chlorophyll biomass decreased and cyanobacteria contribution increased. The microzooplankton (ciliates) abundance and the grazing pressure on primary production were correlatively enhanced (Pérez et al. 2000). Carnivorous species predominated in the zooplankton biomass.
Vertical profiles of bacterioplankton properties (abundance, production, ectoaminopeptidase activity) exhibited pronounced gradients in the upper $50 \mathrm{~m}$ (Fig. 3). Sub-surface maxima, located near the chl a maximum, varied during the cruise between 20 and $45 \mathrm{~m}$ depth. The most striking feature of the profiles was the superimposition of bacterial abundance, bacterial production and ectoaminopeptidase activity with PNAN (Fig. 3) and CYAN abundance (data not shown). Thus, maximum bacterial abundance was always situated near the chlorophyll maximum and reached up to $2 \times 10^{9}$ cells $^{-1}$ the 11,12 and 14 of May. After the wind event of 13 May, as the chlorophyll peak shifted to shallower layers, all categories of pico- and nano-sized organisms accompanied this feature, as well as bacterial activities and biomass. Integrated values $(0$ to $200 \mathrm{~m}$ ) of bacteria (189 and $219 \mathrm{mmol} \mathrm{C} \mathrm{m}^{-2}$ ) and PNAN (122 and $131 \mathrm{mmol} \mathrm{C} \mathrm{m}^{-2}$ ) biomasses were high during 11-12 May (C1) and then decreased slightly (Table 3). Chl $a$ and CYAN followed the same trend but increased again at the end of the month.

\section{Time series of biological and chemical parameters}

Figs. 4 to 8 display time series of CYAN, PNAN, HNAN, bacterial numbers, ectoaminopeptidase activity, thymidine incorporation rates, POC, DOC, particulate and dissolved lipids obtained at 5 and $30 \mathrm{~m}$ from 11 May to 31 May. Table 4 shows the means and percentages of variation in some of these parameters during each $36 \mathrm{~h}$ diel cycle and the significance of the trend with time on a monthly scale.

\section{Photosynthetic microorganisms}

In the surface layer (5 m), CYAN abundance (1.2 to $7.4 \times 10^{4}$ cells $\mathrm{ml}^{-1}$ ) showed no long-term trend whereas PNAN (0.3 to $3.4 \times 10^{3}$ cells ml $\left.{ }^{-1}\right)$ significantly decreased with time ( $p<0.01$, Fig. 4$)$. In the chl a max-

Table 3. Integrated biomasses of bacteria, heterotrophic nanoflagellates (HNAN), phototrophic nanoflagellates (PNAN), cyanobacteria and chl a content (0 to $200 \mathrm{~m}$ ). All profiles made at $14: 00 \mathrm{~h}$

\begin{tabular}{|lccccc|}
\hline Date & $\begin{array}{c}\text { Bacteria } \\
\left(\mathrm{mmol} \mathrm{C} \mathrm{m}^{-2}\right)\end{array}$ & $\begin{array}{c}\text { HNAN } \\
\left(\mathrm{mmol} \mathrm{C} \mathrm{m}^{-2}\right)\end{array}$ & $\begin{array}{c}\text { PNAN } \\
\left(\mathrm{mmol} \mathrm{C} \mathrm{m}^{-2}\right)\end{array}$ & $\begin{array}{c}\text { Cyanobacteria } \\
\left(\mathrm{mmol} \mathrm{C} \mathrm{m}^{-2}\right)\end{array}\left({\left.\mathrm{mg} \mathrm{chl} \mathrm{m}^{-2}\right)}^{\text {Chl } a}\right.$ \\
\hline 11 May & 189 & 24.3 & 121 & 27.4 & 45.2 \\
12 May & 219 & 16.0 & 131 & 34.6 & 47.8 \\
14 May & 186 & 14.4 & 59.7 & 24.1 & 32.9 \\
15 May & 170 & 12.9 & 55.3 & 14.1 & 25.1 \\
31 May & 165 & 15.0 & 53.8 & 28.7 & 35.5 \\
\hline
\end{tabular}




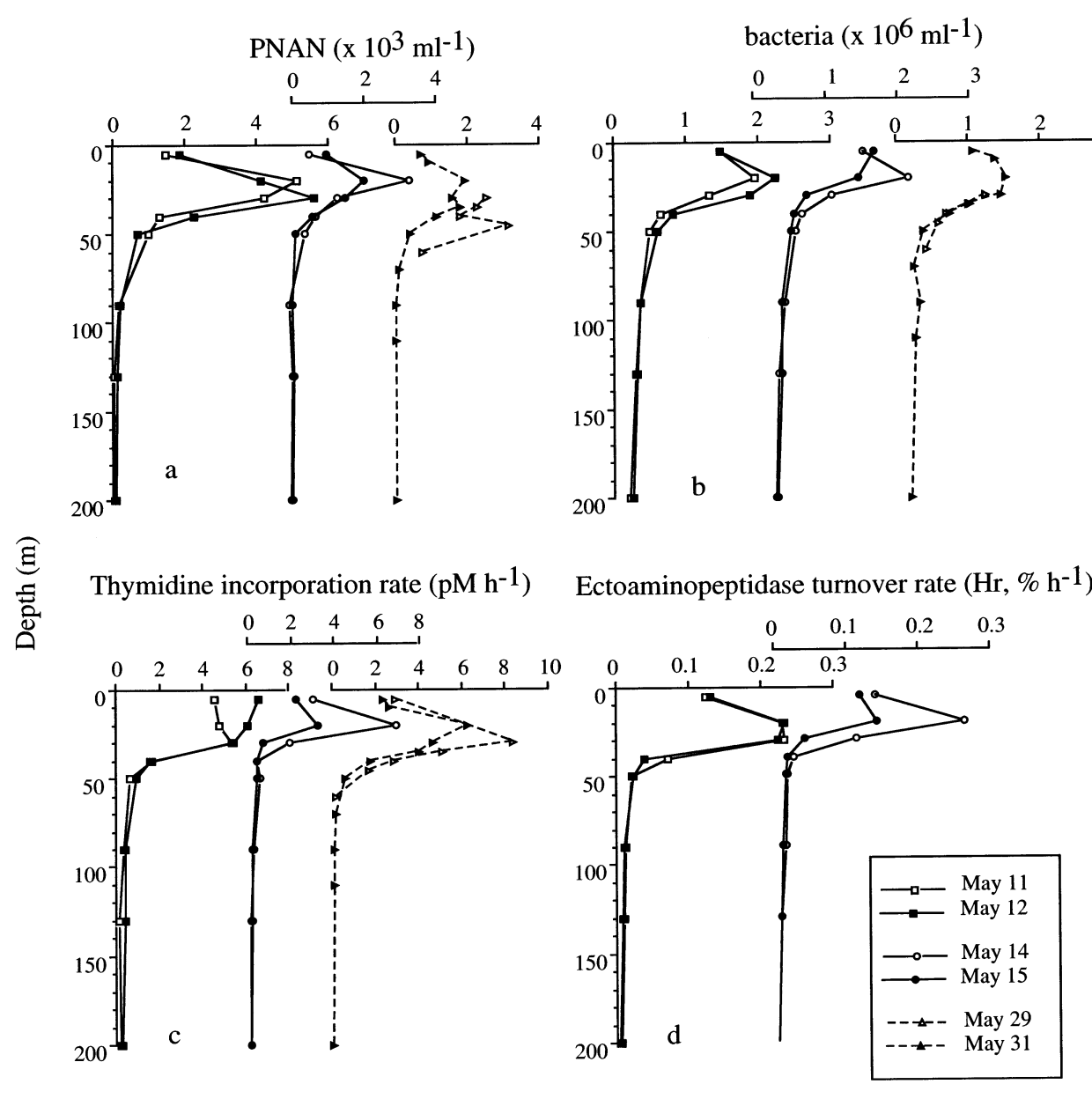

Fig. 3. Vertical profiles 0 to $200 \mathrm{~m}$ of (a) phototrophic nanoflagellates (PNAN), (b) bacterial abundance, (c) thymidine incorporation rates and (d) ectoaminopeptidase turnover rates (Hr) at the Dyfamed station during May 1995. 11, 12, 13, 14 and 31 May: 14:00 hi 29 May: 18:00 h

ima layer $(30 \mathrm{~m})$, high amplitudes of both organisms were observed during $\mathrm{C} 1$. Due to the new position of chl a peak at $20 \mathrm{~m}$, an important decrease of abundances was observed at $30 \mathrm{~m}$ at C2. During C3 and C4, CYAN abundance increased again but still exhibited high amplitudes. At this depth $(30 \mathrm{~m})$, significant changes between day and night samples were observed for PNAN during C1 and C3 ( $p<0.05)$. On the monthly scale however, without data out of the chl a peak (see 'Materials and methods'), CYAN significantly increased $(\mathrm{p}<0.01)$ while PNAN significantly decreased $(p<0.01)$.

\section{Heterotrophic biomass and activities}

Bacterial numbers often exceeded $1 \times 10^{6}$ bacteria $\mathrm{ml}^{-1}$. The bacterial biomass ranged from 1.65 to
$3.20 \mu \mathrm{M} \mathrm{C}$ at $5 \mathrm{~m}$ (Table 4). At this depth, bacterial number, HNAN, and thymidine incorporation rates decreased significantly through the period of study whereas a positive trend characterized the ectoaminopeptidase turnover rate (Hr) (Figs. $5 \& 6$, Table 4). Bacterial biomass ranged from 1.0 to $4.1 \mu \mathrm{M}$ C at $30 \mathrm{~m}$. At $30 \mathrm{~m}$, the monthly scale trend was unsignificantly different from zero for bacterial abundance and production whereas it was negative for HNAN abundance and ectoaminopeptidase turnover rate (Table 4). At each $36 \mathrm{~h}$ cycle and at both layers studied, variation of thymidine incorporation rates and ectoaminopeptidase activity were higher than those of bacterial numbers. Coefficients of variations around each $36 \mathrm{~h}$ time series ranged from 15 to $35 \%$ for thymidine incorporation rates, from 9 to $45 \%$ for ectoaminopeptidase activity, and from 8 to $22 \%$ for bacterial numbers. 


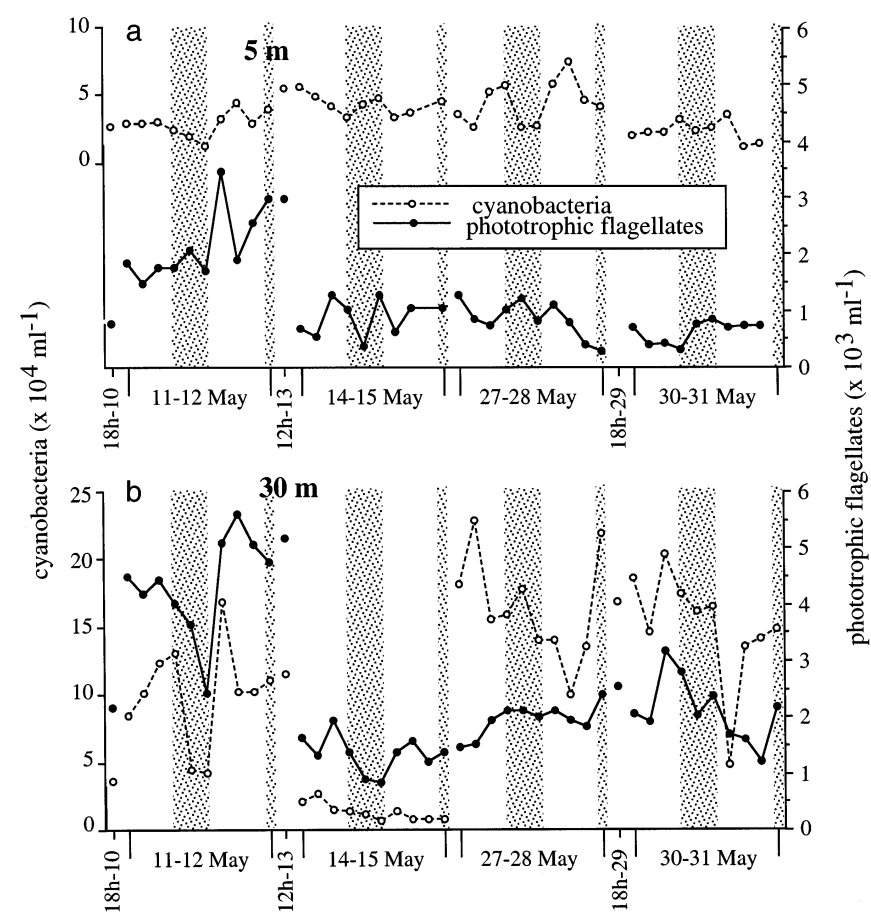

Fig. 4. Evolution of abundance of cyanobacteria and phototrophic nanoflagellates at (a) $5 \mathrm{~m}$ and (b) $30 \mathrm{~m}$. In Figs. 4 to 8 , the $x$ axis is represented as follows: each $36 \mathrm{~h}$ time series begins at 10:00 $\mathrm{h}(\mathrm{UT}+2)$ and ends at 22:00 $\mathrm{h}(\mathrm{UT}+2)$ the following day, and includes 10 points on a linear scale $(10: 00$, 14:00, 18:00, 22:00, 02:00, 06:00, 10:00, 14:00 18:00, and 22:00 h). Shaded area corresponds to night. Note that the $x$ scale is not linear with time between each $36 \mathrm{~h}$ time series

Ectoaminopeptidase turnover rate and thymidine incorporation rates were positively correlated at $30 \mathrm{~m}$ $(\mathrm{r}=0.72, \mathrm{n}=38)$; however, at $5 \mathrm{~m}$ depth, correlation was unsignificant $(\mathrm{r}=0.15, \mathrm{n}=39)$ mostly because production and ectoaminopeptidase activity were in an opposite phase at the end of the month (Fig. 6). Significant difference between day and night samples characterized HNAN during $\mathrm{C} 4$ at $5 \mathrm{~m}, \mathrm{C} 2$ and $\mathrm{C} 3$ at $30 \mathrm{~m}$, and thymidine incorporation rates during $\mathrm{C} 1$ at $5 \mathrm{~m}$ ( $p<0.05$ for all comparisons).

\section{POC and lipid content}

POC concentrations varied from 6.4 to $20 \mu \mathrm{M} \mathrm{C}$ and decreased significantly with time in both surface and chlorophyll maxima layers. Particulate carbon-lipids (C-PL) varied from 0.5 to $7.2 \mu \mathrm{M} \mathrm{C}$ at $5 \mathrm{~m}$ and from 0.4 to $7.9 \mu \mathrm{M} \mathrm{C}$ at $30 \mathrm{~m}$, but decreased significantly with time only at the surface (Fig. 7, Table 4). In the surface layer, C-PL exhibited peaks around 10:00 h although there was never a significant difference between night and day. Means of lipid contribution to POC decreased

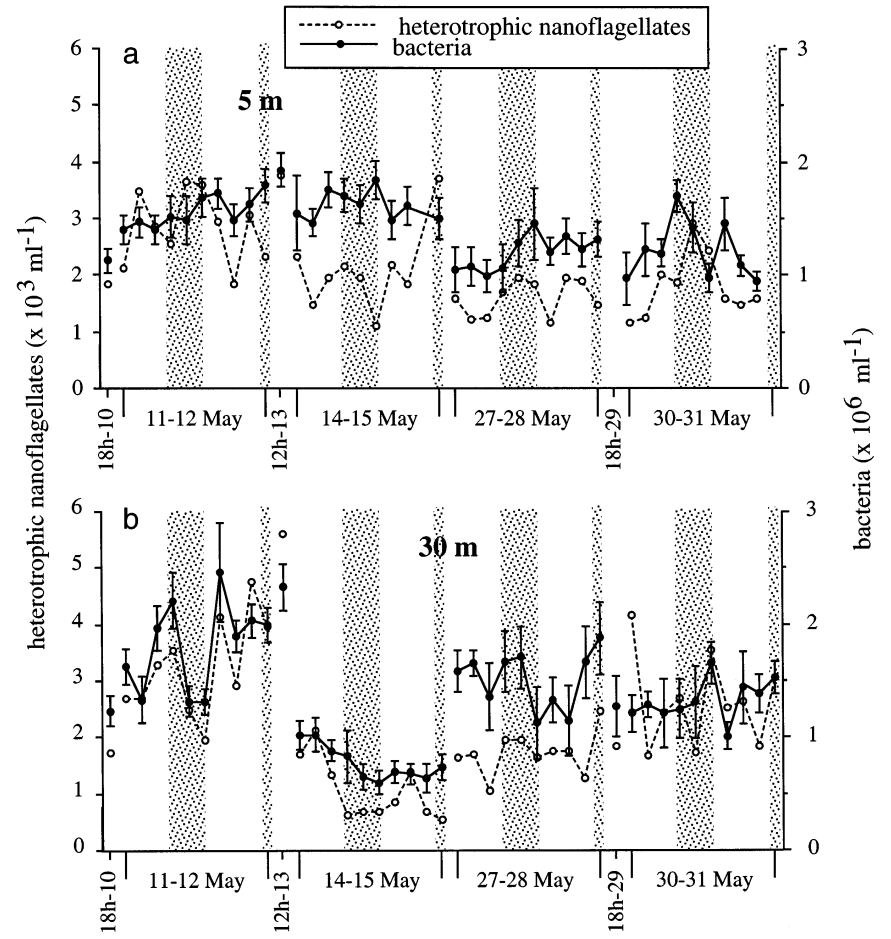

Fig. 5. Evolution of abundance of bacteria and heterotrophic nanoflagellates at (a) $5 \mathrm{~m}$ and (b) $30 \mathrm{~m}$. Error bar for bacterial abundance is the SD between slide fields

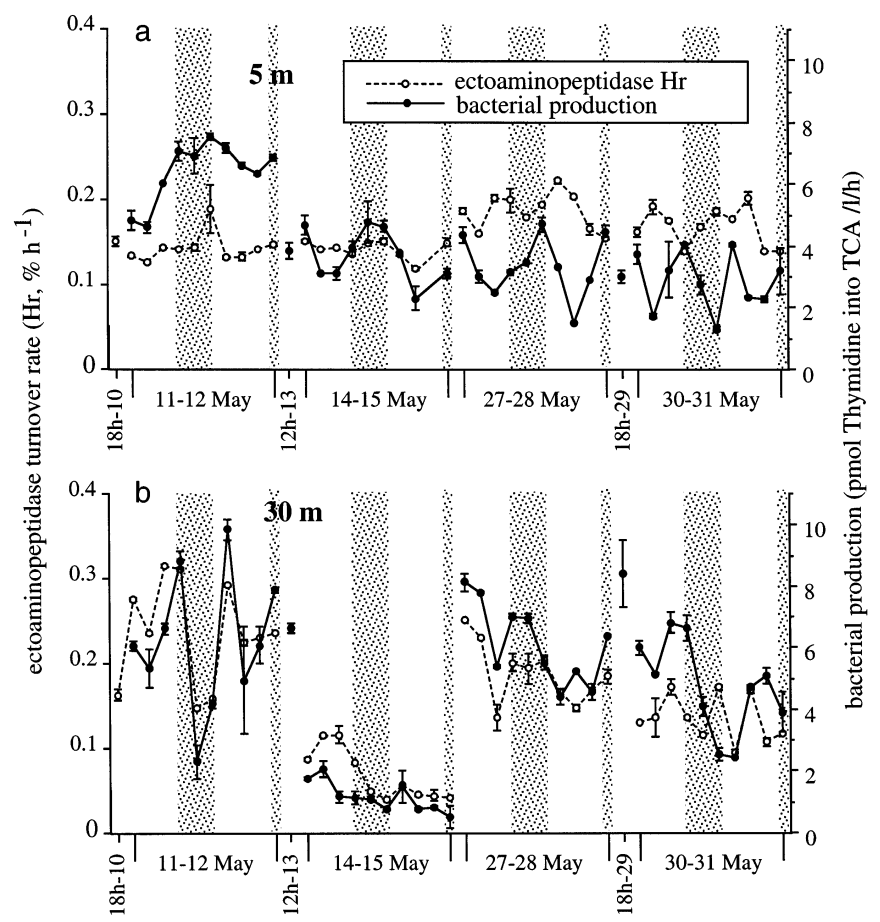

Fig. 6. Evolution of bacterial production (expressed in thymidine incorporation rates) and ectoaminopeptidase turnover rate at (a) $5 \mathrm{~m}$ and (b) $30 \mathrm{~m}$. Error bar for bacterial production and ectoenzymatic activity is the variability between duplicates 
( $28 \%$ at the beginning of the study, $14 \%$ at the end) but not significantly with time in the surface layer while the lipolysis index (LIp), a tracer of acyl-lipid transformation under enzymatic hydrolysis (Goutx et al. 2000, Striby 2000), increased significantly during

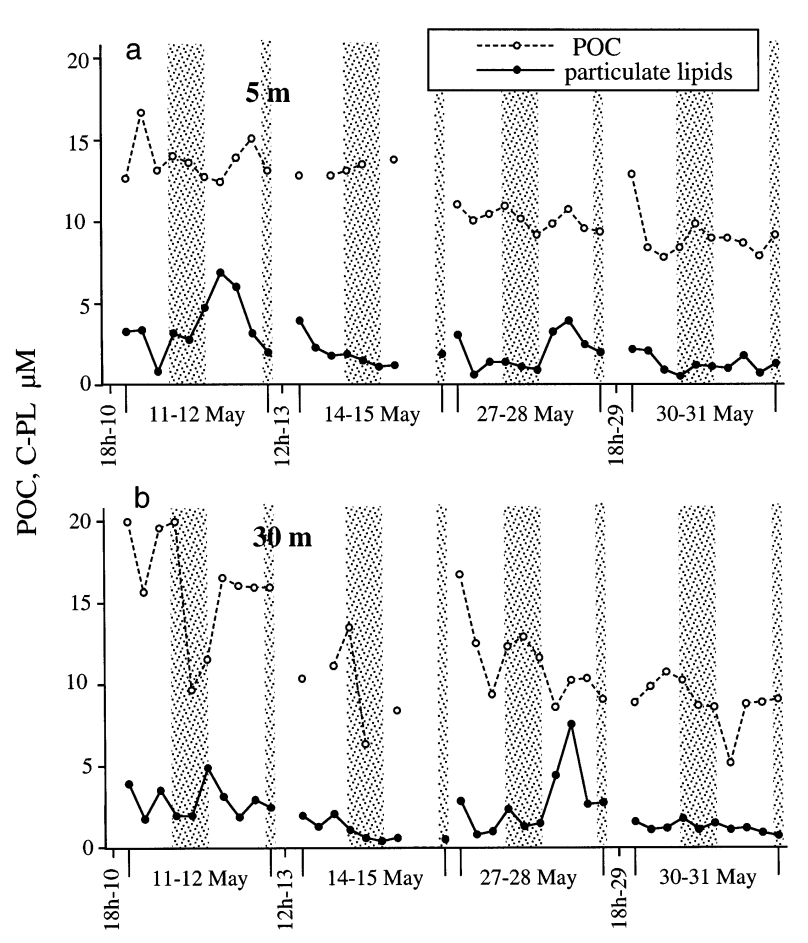

Fig. 7. Evolution of particulate organic carbon (POC) and particulate carbon-lipids (C-PL) at (a) $5 \mathrm{~m}$ and (b) $30 \mathrm{~m}$ the month (Table 5). At $30 \mathrm{~m}$, the lipid content in POC was lower than in the surface during $\mathrm{C} 1$ and did not change significantly with time. The LIp was higher at this depth than in the surface layer except at C3. At the

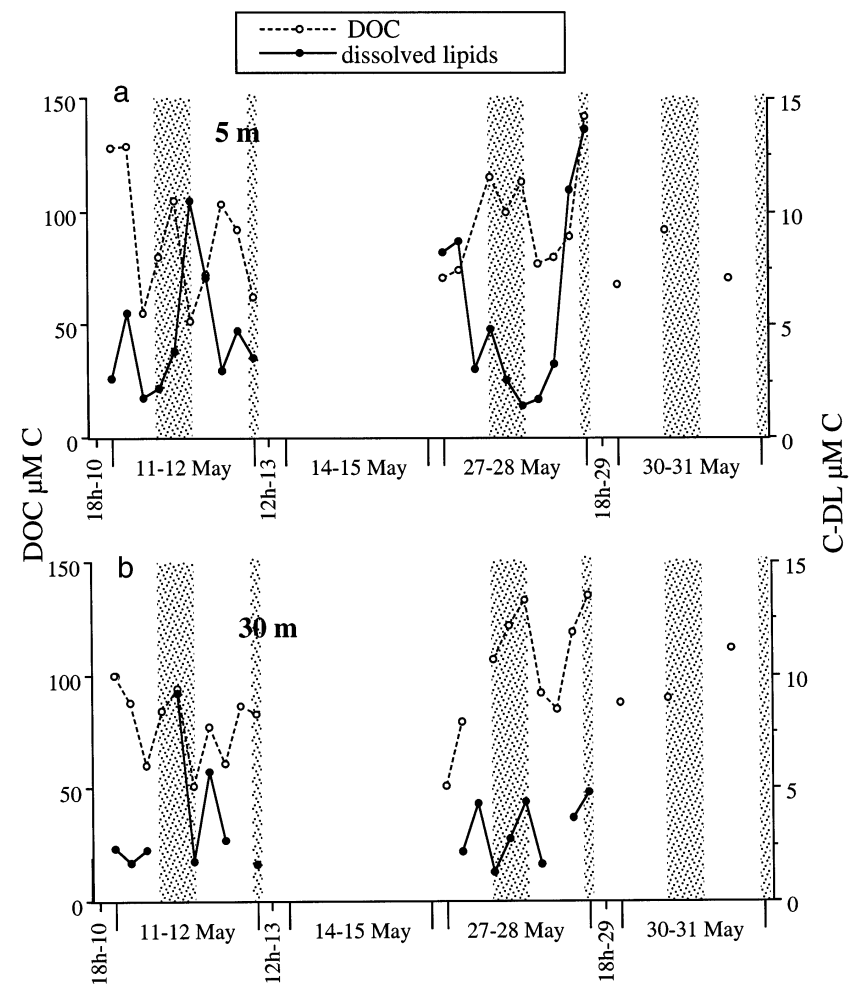

Fig. 8. Evolution of dissolved organic carbon (DOC) and dissolved carbon-lipids (C-DL) at (a) $5 \mathrm{~m}$ and (b) $30 \mathrm{~m}$

Table 4. Means and standard deviation (SD, in parentheses) during each $36 \mathrm{~h}$ diel cycle and trends in long-term time series. Auto: autotrophic biomass, BB: bacterial biomass, Tdr: thymidine incorporation rates, Hr: ectoaminopeptidase turnover rate, POC: particulate organic carbon, C-PL: particulate carbon-lipids, DOC: dissolved organic cabon, C-DL: dissolved carbon-lipids. For long-term trend each parameter is fitted to a linear regression with time. ns: slopes not statistically different from zero ( $p>0.05$, variance analysis $F$-test). +: positive slopes, - : negative slopes at $(--,++) \mathrm{p}<0.01$ and $(-,+) \mathrm{p}<0.05)$; nd: no data

\begin{tabular}{|c|c|c|c|c|c|c|c|c|c|}
\hline & Cycle & $\begin{array}{l}\text { Auto } \\
(\mu \mathrm{M} \mathrm{C})\end{array}$ & $\begin{array}{c}\mathrm{BB} \\
(\mu \mathrm{M} \mathrm{C})\end{array}$ & $\begin{array}{c}\mathrm{Tdr} \\
\left(\mathrm{pmol} \mathrm{l}^{-1} \mathrm{~h}^{-1}\right)\end{array}$ & $\begin{array}{c}\mathrm{Hr} \\
\left(\% \mathrm{~h}^{-1}\right)\end{array}$ & $\begin{array}{l}\text { POC } \\
(\mu \mathrm{M} \mathrm{C})\end{array}$ & $\begin{array}{c}\text { C-PL } \\
(\mu \mathrm{M} \mathrm{C})\end{array}$ & $\begin{array}{l}\mathrm{DOC} \\
(\mu \mathrm{M} \mathrm{C})\end{array}$ & $\begin{array}{c}\mathrm{C}-\mathrm{DL} \\
(\mu \mathrm{M} \mathrm{C})\end{array}$ \\
\hline $5 \mathrm{~m}$ & CI 11-12 May & $2.2(1.0)$ & $2.6(0.2)$ & $6.4(0.9)$ & $0.14(0.02)$ & $13.8(1.3)$ & $3.8(1.9)$ & $88(32)$ & $4.5(2.6)$ \\
\hline \multirow[t]{3}{*}{ Means (SD) } & C2 14-15 May & $1.9(0.7)$ & $2.7(0.2)$ & $3.7(0.9)$ & $0.14(0.01)$ & $13.2(0.4)$ & $2.0(0.9)$ & nd & nd \\
\hline & C3 27-28 May & $2.5(0.6)$ & $2.0(0.2)$ & $3.4(1.0)$ & $0.18(0.02)$ & $10.2(0.7)$ & $2.1(1.2)$ & $95(24)$ & $6.0(4.4)$ \\
\hline & C4 30-37 May & $2.0(0.2)$ & $2.0(0.4)$ & $2.9(0.9)$ & $0.16(0.02)$ & $9.2(1.5)$ & $1.3(0.6)$ & $77(17)$ & nd \\
\hline $30 \mathrm{~m}$ & CI 11-12 May & $4.0(1.6)$ & $3.0(0.7)$ & $6.2(2.2)$ & $0.24(0.6)$ & $16.1(3.4)$ & $3.0(1.1)$ & $78(20)$ & $3.4(2.7)$ \\
\hline \multirow[t]{3}{*}{ Means (SD) } & C2 14-15 May a & $1.4(0.8)$ & $1.3(0.3)$ & $1.1(0.5)$ & $0.67(0.3)$ & $10.0(2.7)$ & $1.1(0.7)$ & nd & nd \\
\hline & C3 27-28 May & $2.5(0.7)$ & $2.5(0.4)$ & $6.1(1.3)$ & $0.18(0.03)$ & $11.4(2.4)$ & $2.9(2.1)$ & $102(27)$ & $3.1(1.3)$ \\
\hline & C4 30-37 May & $2.5(0.4)$ & $2.2(0.3)$ & $4.7(1.5)$ & $0.13(0.03)$ & $8.9(1.5)$ & $1.3(0.3)$ & $96(13)$ & nd \\
\hline \multirow{2}{*}{\multicolumn{2}{|c|}{$\begin{array}{l}\text { Trend with time } 5 \mathrm{~m} \\
\text { Trend with time chl peak }\end{array}$}} & ns & -- & -- & ++ & -- & -- & ns & ns \\
\hline & & -- & ns & ns & -- & -- & ns & + & ns \\
\hline \multicolumn{10}{|c|}{$\begin{array}{l}\text { aAt } 30 \text { m depth during Cycle } 2 \text { (14-15 May) most of the samples were deeper than the chl peak which moved up to } 20 \mathrm{~m} \\
\text { depth (see text) }\end{array}$} \\
\hline \multicolumn{10}{|c|}{$\begin{array}{l}{ }^{b} \text { For } 30 \mathrm{~m} \text { depth only samples corresponding to the chl peak were included in the regression ( } \mathrm{n}=21 \text { to } 41 \text { according to the } \\
\text { parameter) }\end{array}$} \\
\hline
\end{tabular}


(Table 6), assuming that all bacteria were retained on the GF/F filters. Bacterial biovolume during the period of the study (post bloom conditions) was relatively large $\left(0.08-0.11 \mathrm{\mu m}^{3}\right)$ and was in the size range of bacteria retained by the GF/F filter (Lee \& Fuhrman 1987). Heterotrophic nanoflagellates, the highest category of heterotrophic organisms in terms of carbon after bacteria, constituted only $2 \pm 0.5$ and $2.2 \pm 1.1 \%$ of POC at 5 and $30 \mathrm{~m}$, respectively.

As expected, after computation of autotrophic biomass with the depth-dependant conversion factors, autotrophic biomass appears then not so much different (in terms of carbon) between surface and chlorophyll maximum layer. The difference which still existed during the termination of the bloom observed on the beginning of the cruise (11-12 May: $2.2 \pm$ $1.0 \mu \mathrm{M} \mathrm{C}$ at $5 \mathrm{~m}, 4.0 \pm 1.6 \mu \mathrm{M} \mathrm{C}$ at $30 \mathrm{~m}$ ), then disappeared (30-31 May: $2.0 \pm 0.2 \mu \mathrm{M} \mathrm{C}$ at $5 \mathrm{~m}, 2.5 \pm$ $0.6 \mu \mathrm{M} \mathrm{C}$ at $30 \mathrm{~m})$. Autotrophic biomass ranged 8 to $28 \%$ of POC at $5 \mathrm{~m}$, and 5 to $36 \%$ within the chlorophyll maximum $(30 \mathrm{~m})$.

At $5 \mathrm{~m}$, bacterial biomass exceeded autotrophic biomass until mid-May (average BB/AUTO ratio $1.4 \pm 0.8$ and $1.7 \pm 0.5$ for $\mathrm{C} 1$ and $\mathrm{C} 2$, respectively, Table 6 ). In the chlorophyll maximum layer, autotrophic biomass was higher than bacterial biomass when chl a peaked at the beginning of the cruise (BB/AUTO ratio $0.7 \pm 0.2$ during C1). After mid-May the ratios reached values close to 1 (27-28 May and 30-31 May) at both depths.

The sum of autotrophic biomass, BB and HNAN biomass was assumed to represent living POC. Non-living

Table 6. Means (SD) during each $36 \mathrm{~h}$ diel cycle and trends in long-term time series. BB/AUTO: carbon ratio of bacterial biomass to autotrophs, BB/POC: bacterial biomass-C to POC percentage, NL POC/POC: non-living particulate organic carbon/POC percentage. nd and code for trends as in Table 4

\begin{tabular}{|lcccc|}
\hline Cycle & & $\begin{array}{c}\text { BB/AUTO } \\
\text { ratio }\end{array}$ & $\begin{array}{c}\text { BB/POC } \\
(\%)\end{array}$ & $\begin{array}{c}\text { NL POC/ } \\
\text { POC (\%) }\end{array}$ \\
\hline $5 \mathrm{~m}$ & C1 11-12 May & $1.4(0.8)$ & $19(3)$ & $62(9)$ \\
Means (SD) & C2 14-15 May & $1.7(0.5)$ & $20(2)$ & $65(5)$ \\
& C3 27-28 May & $0.8(0.2)$ & $20(3)$ & $53(9)$ \\
& C4 30-37 May & $1.1(0.2)$ & $23(6)$ & $53(8)$ \\
$30 \mathrm{~m}$ & CI 11-12 May & $0.7(0.2)$ & $19(3)$ & $52(9)$ \\
Means (SD) & C2 14-15 May & $1.2(0.4)$ & $14(3)$ & $72(7)$ \\
& C3 27-28 May & $1.0(0.2)$ & $23(5)$ & $53(10)$ \\
C4 30-37 May & $1.1(0.3)$ & $25(5)$ & $47(5)$ \\
Trend with time 5 m & -- & ns & -- \\
Trend with time chl peak & ++ & ++ & ns \\
at 30 m depth during Cycle 2 (14-15 May) most of the samples \\
were deeper than the chl peak which moved up to 20 m depth \\
(see text) \\
bFor 30 m depth only samples corresponding to the chl peak \\
were included in the regression (n = 21 to 41 according to the \\
parameter)
\end{tabular}

POC (i.e. the difference between POC and living POC) represented in most cases more than $50 \%$ of POC. Significant $(\mathrm{p}<0.01)$ long-term decrease was obtained for $\mathrm{POC}$, non-living $\mathrm{POC}$ and percentage of non-living POC in POC at $5 \mathrm{~m}$ during the course of the study (Tables 4 \& 6). At the chlorophyll peak, the same pattern was observed for all parameters except the latter, which showed no tendency.

\section{Potential hydrolysis of non-living POC}

In an attempt to point out the origin of bacterial carbon resources, we estimated a flux of potential hydrolysis $(\mathrm{PH})$ of particulate detritus by multiplying ectoaminopeptidase turnover rates with the calculated non-living POC. The resulting flux ranged from 5 to

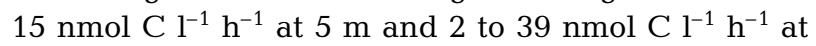
$30 \mathrm{~m}$. There was a significant $(\mathrm{p}<0.01)$ decrease of this flux with time at $5 \mathrm{~m}$ depth and in the chlorophyll peak during the course of the study.

\section{DISCUSSION}

\section{Estimates of carbon from living biomass and detritus}

\section{Living biomass}

To avoid problems related to carbon/chl a conversion factors for the autotrophic biomass estimate (Li et al. 1992, Buck et al. 1996), we took into account both phytoplankton species composition and photoacclimation. At the chlorophyll maximum depth, the peak of autotrophic biomass can be strongly dampened when converted in terms of carbon through a $\mathrm{C} / \mathrm{chl}$ a conversion factor that considers photoacclimation (Taylor et al. 1997). We found that the $\mathrm{C} / \mathrm{chl}$ a ratio between the $50 \%$ light level (5 m) and the $3 \%$ light level $(30 \mathrm{~m})$ differed by a factor of 3.5. This value fell in the upper range of values reported by Geider et al. (1997) in their model at $15^{\circ} \mathrm{C}$. Similarly, Li et al. (1992) and Campbell et al. (1994) used the factor 3 between the deep maximum chlorophyll layer and the surface mixed layer.

Heterotrophic living biomass was estimated as bacterial + heterotrophic nanoflagellate biomasses. As ciliates represented only $3 \%$ of $\mathrm{BB}$ (6.3 mmol C m${ }^{-2}$, Pérez et al. 2000), they were not taken into acount. The abundance/carbon conversion factor used in this study for bacteria $\left(20 \mathrm{fg} \mathrm{C} \mathrm{Cell}^{-1}\right)$ is sometimes considered to be overestimated in oligotrophic systems. However, at the time of sampling the system was not fully 
oligotrophic, bacterial numbers often exceeding $1 \times 10^{6}$ bacteria $\mathrm{ml}^{-1}$. The appropriateness of the $20 \mathrm{fg} \mathrm{C}^{\mathrm{C}} \mathrm{cell}^{-1}$ factor was further confirmed by applying the carbon to volume relationship cited in Norland (1993) to our measured biovolumes (ranging from 0.08 to $0.11 \mu^{3}$ ). Another potential problem might be an overestimation of bacterial abundance counted by epifluorescence microscopy due to interference with Prochlorococcus cells. However, during the cruise, the abundances of Prochlorococcus were estimated by Martin (1997) using flow cytometry, and ranged from 0.7 to $1 \times 10^{4}$ cells $\mathrm{ml}^{-1}$, less than the error of bacterial counts.

\section{Detrital carbon}

Direct estimation of detrital organic fraction in POC, to our knowledge, has not yet been reported. Indirect estimates of particulate detritus have been tentatively depicted in an approach combining transmissiometry and cytometry (Chung et al. 1998, Claustre et al. 1999). Non-living organic detrital particles were estimated to account, on average, for $50 \%$ (20 to $60 \%$ ) of the beam attenuation coefficient of particles in surface layers ( 0 to $200 \mathrm{~m}$ ) of the equatorial Pacific (Chung et al. 1998) and 43 to $55 \%$ along $150^{\circ} \mathrm{W}$ in the Pacific Ocean (Claustre et al. 1999). But these methods, while promising because usable with a high frequency of sampling, are still unable to determine detrital carbon. Direct estimates of detrital particles have been made by counting DAPI-yellow particles (Mostajir et al. 1995), or some transparent exopolymer particles (Passow \& Alldredge 1994), but conversion of particle abundance in terms of carbon still suffers from problems caused by conversion factors. Our approach consisted of an estimation of the detritic carbon by subtracting living POC from total POC. By considering assumptions and cautions used in the estimation of autotrophic and heterotrophic biomass, we found that in most cases more than half of the POC was in a nonliving form. Extreme values ranged from 33 to $83 \%$. Our values are thus of the same order as those of Cho \& Azam (1990) for bulk seawater (the ocean's euphotic zone), where bacterial biomass + autotrophic biomass comprised about $50 \%$ of the POC. Higher values have been described in a diatom-based marine snow, where non-living POC represented 87 to $99 \%$ of the total aggregate carbon (Simon et al. 1990).

\section{Evolution of the trophic web}

During the period of observation at the Dyfamed site, a transition from mesotrophy to oligotrophy was depicted through the evolution of nutrients, primary pro- duction and diagnostic pigments (Andersen \& Prieur 2000, Vidussi et al. 2000). The culminating and declining phytoplankton bloom phases were observed (Andersen \& Prieur 2000, Vidussi et al. 2000). Abundance and biomass of bacteria and cyanobacteria were within the upper range reported for comparable offshore regions of the Mediterranean Sea (Fernandez et al. 1994, Van Wambeke et al. 1996, Yoro et al. 1997, Pedros-Alio et al. 1999) at the beginning of the study. While the numbers of bacteria HNAN and PNAN decreased, the rather constant number of cyanobacteria depicted the same evolution of the system towards oligotrophy.

With the precautions taken to determine the autotrophic and bacterial biomass, we observed few variations in the relative contributions of these 2 biomasses. The ratio BB/AUTO ranged from 0.7 to 1.7, much lower than those (up to 6) reported by Cho \& Azam (1990), who used a constant $\mathrm{C} / \mathrm{chl}$ a ratio of 50 . Autotrophic biomass exeeded bacterial biomass at the beginning of the cruise in the chl a peak, but not at $5 \mathrm{~m}$. Then, the ratio evolved towards an equilibrium between heterotrophic and autotrophic biomasses during the month. It seems, from our data and those of Buck et al. (1996), that high disequilibrium towards heterotrophy observed in oligotrophic environments could be due to an inappropriate choice of conversion factors as discussed above. However, true oligotrophic conditions did not prevail at this time, which was depicted as preoligotrophy. The other conclusion drawn from our data is that ratios estimated only from surface values (interesting because they allow high frequency of sampling by continuous pumping during ship transects) are not necessarily representative of the other layers in the euphotic zone.

During the course of the study, the ratio of non-living POC to total POC significantly decreased with time in the surface but remained unchanged in the chl a peak. This suggests a different evolution in the functioning of the food web at these 2 layers. The non-living POC to total POC ratio has been shown to decrease with the number of trophic levels in top-down manipulated mesocosms (Christaki \& Van Wambeke 1995), a lower ratio suggesting that non-living POC turns over more rapidly in complex food webs. It is thus likely that more oligotrophic conditions, appropriate for the development of more complex microbial food webs, induced an optimal use of available detrital particulate carbon in the surface.

\section{Short-scale variability}

During the cruise, bacterial properties were tightly coupled to autotrophs (Fig. 3) which have to modify 
activity and physiology with light availability. Day/ night periodicity also was an important parameter regulating zooplankton feeding activity on autotrophs (Goutx et al. 2000). In this context, we expected to observe changes in bacterial carbon sources and feeding strategies on the diel scale. Overall, diel variability of bacterial biomass (CV values ranging from 8 to $22 \%$ ) was lower than that of bacterial production (CV ranging from 15 to $35 \%$ ). The net trends of bacterial biomass over each $36 \mathrm{~h}$ diel study were much lower than time-integrated bacterial production rates, and sometimes negative, showing evidence of an active regulatory mechanism of bacterial populations. Preypredator relationships might be involved. Indeed, heterotrophic nanoflagellates were observed, although not systematically, in opposition of the phase with bacteria $(\mathrm{C} 2,5 \mathrm{~m})$. Conversely, predation of higher organisms like ciliates certainly accounted for the regulation of nanoflagellates numbers (Gonzalez et al. 1988, Perez et al. 2000).

Bacterial production was shown to be significantly higher at night only during $\mathrm{C} 1$ at $5 \mathrm{~m}$ depth, but neither the day-night difference nor the occurrence of peaks at a particular time of the day were reproducible on all cycles studied. Nevertheless, the daily cycle of bacterial production should be expected with integrated values on the entire thickness of the chlorophyll peak. In the western Mediterranean, Gasol et al. (1998) observed an increase in bacterial production in the bulk deep chlorophyll maximum layer around noon, but this signal was not visible at the different discrete depths because of microscale vertical variability. However, this daily variation in bacterial production was not observed at all the stations studied by these authors and was better reflected by data from the leucine method than by data from the thymidine method that we used. Moreover, in the eastern Meditterranean (Zohary \& Robarts 1992), thymidine incorporation per cell exhibited a diel pattern when absolute rates did not.

Diurnal variations of protease activity have been described in lakes (Halemejko \& Chrost 1986) and in seawater (Middelboe \& Søndergaard 1993, Bochandsky et al. 1995). On the contrary, in a long-term study in the Bay of Villefranche (northwestern Mediterranean), aminopeptidase activity did not show any clear trend related to daytime (Karner \& Rassoulzadegan 1995), as was the case in our study. Bochandsky et al. (1995) and Christaki \& Van Wambeke (1995) reported that zooplankton activity enhances ectoproteolytic activity in experiments. The influence of night migration was particularly evidenced during C3; carnivorous zooplankton species migrated at night and were responsible for an episodic pulse of particulate lipids into sediment traps (Goutx et al. 2000). During C3, bacterial produc- tion and ectoaminopeptidase activity were also high on both nights investigated.

Lack of diel periodicity for bacterial activities was also observed in marine systems influenced by tidal mixing, sediment resuspension or fronts (Christaki et al. 1996). The Dyfamed site is usually situated outside the influence of the coast and of the Ligurian Current. Andersen \& Prieur (2000) demonstrated that horizontal advection in the euphotic zone remained weak during the period of the study but some vertical motion due to Ekman pumping existed. In addition, meteorological conditions (rain, cloudy days, winds) superimposed their effects on diel variability and consequently, probably prevented us from obtaining reproducible diel patterns (Coffin et al. 1993).

Under those conditions, relating bacterial activities to evolution in their resources was not systematically possible on a short-time scale. For example, high frequency variability of DOC was observed at 5 and $30 \mathrm{~m}$, which seems to indicate the transitory imbalances between sources and fates of DOC (Carlson \& Ducklow 1995). Possible sources of DOC are exudation from phytoplankton, release from zooplankton excretion (Jumars et al. 1989), and dissolution of particles through biotic and abiotic processes (Sempéré et al. 2000), whereas consumption needs to be attributed to bacterial assimilation followed by incorporation in the microbial loop or lost as $\mathrm{CO}_{2}$ through respiration. Computation of bacterial growth efficiency (BGE) from bacterial production rates and periods of net DOC decrease, even with the more favourable thymidine

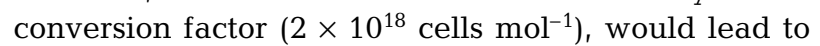
BGE as low as $0.1 \%$. Even if exceptionally low values of BGE have been reported in oligotrophic areas (Cherrier et al. 1996), published values are in most cases 10 times higher than this value (del Giorgio \& Cole 1998). By considering integrated DOC variations in order to avoid problems caused by short-term evolution in vertical structures, Gasol et al. (1998) were successful in explaining decreases of DOC, but were not able to explain abrupt increases in DOC. Strong variations on short-time scales have also been attributed, not only to biological activity, but also to horizontal advection and biological patchiness (Kepkay \& Wells 1992). We also considered 1 additional hypothesis to explain DOC variations, i.e. the abiotic formation of exopolymeric particles as reported by Kepkay \& Johnson (1988), that would contribute to DOC removal together with bacterial production and respiration which often accompany such processes. Indeed, agregation/disagregation characterized small scale variation in organic matter distribution in the water column at the time of sampling (Stemmann et al. 2000), and large agregates sedimentation was observed (Goutx et al. 2000). 
Variations in some particular components of DOC, however, indicate a strong coupling with heterotrophic bacteria on a time scale of a few hours. For example, in surface waters during $\mathrm{C} 1$, the inverse correlation between dissolved triglycerides (TGd) and bacterial production (Fig. 9) revealed specific utilization of these compounds by bacteria. Simultaneous release of TGd hydrolysis products (free fatty acids) suggested that bacterial hydrolytic enzyme activity was responsible for TG degradation. Calculated TGd turnover rate $\left(3.6 \mathrm{~d}^{-1}\right)$ fell within the range reported for highly degradable molecules, indicating efficient substratebacterial affinity (Kiel \& Kirchman 1999).

\section{Partition between bulk DOC and non-living POC for bacterial resources}

We also found in lipid indices, indications of evolution in utilization of DOC on longer scales. The selective decrease in dissolved lipids compared to the bulk DOC pool observed in the chl a peak also suggests that bacteria utilized increased fractions of carbon sources in the DOC. This was also seen through the free fatty acid fraction in DOC, which decreased from 1.08 to $0.27 \%$. The lipolysis index, determined in the particulate fraction, demonstrates also to some extent these trends: It remained quite constant at $30 \mathrm{~m}$ depth (0.31-0.39), indicating that detrital POC had no time to accumulate, and thus to be modified in quality by bacterial degradation; thus the products of lipid hydrolysis (free fatty acids) stayed equilibrated compared to the substrates of hydrolysis (lipid esters). In contrast, at $5 \mathrm{~m}$, the lipolysis index of POC increased (from $0.23-0.21$ at $\mathrm{C} 1$ and $\mathrm{C} 2$ to $0.38-0.32$ at $\mathrm{C} 3$ and $\mathrm{C} 4$ ), indicating an increasing hydrolysis of POC.

To confirm these hypotheses, we made a tentative carbon budget to examine the origin of bacterial carbon resources. BP was calculated by using both the theoretical and empirical values which cover the best probable estimates of bacterial production calculated using thymidine technique in the western Mediterranean (see 'Materials and methods'). BCD was calculated from BP assuming a $20 \%$ BGE, which is an average value in open-sea oligotrophic systems (Carlson \& Ducklow 1996, del Giorgio \& Cole 1998) and in the Mediterranean (Zweifel et al. 1993, Sempéré et al. 1998). Carbon resources used by bacteria to satisfy BCD were partitioned between detrital POC and DOC, and we considered a third pool, ultralabile DOC. Ultralabile DOC turns over on a time scale of few hours and was assumed to have no time to accumulate in bulk DOC. Typically, most of the molecules included in this ultralabile pool are sugars, amino acids (free and com- bined) and lipid moieties, and most commonly, molecules issued from rapid hydrolysis. Taking into account data from Skoog et al. (1999), Kiel \& Kirchman (1999) and references therein, we considered that up to $40 \%$ of the BCD should come from this ultralabile pool in oligotrophic environments (the sum of DFAA + DCAA 15 to $25 \%$, glucose $5 \%$, labile polysaccharides $10 \%$, ultralabile lipids and other labile compounds 5\%). Thus, to satisfy BCD, the remaining $60 \%$ must be met by semi-labile pools, i.e. bulk DOC or detrital POC.

Measuring detritus degradation rates remains difficult. Most estimates are made on batch incubations (Jahnke \& Craven 1995, Sempéré et al. 2000), which are time-consuming and thus inappropriate for high frequency studies. Fluorescent analogs like MCA-leu are easier to manipulate although their significance concerning fluxes remains unclear (Crottereau \& Delmas 1998, Jørgensen et al. 1999, Lamy et al. 1999). Nevertheless, Hoppe et al. (1993) calculated an in situ hydrolysis rate of particulate organic nitrogen (PON) by combining ectoaminopeptidase turnover rates determined with MCA-leu as substrate and concentrations of PON. Based on this model, our $\mathrm{Hr}$ values derived from MCA-leu hydrolysis (mean $0.038 \pm$ $0.014 \mathrm{~d}^{-1}, \mathrm{n}=78$ ) fell in the lower range of turnover rates of the slowly degradable pool of POC calculated from experiments investigating the biodegradation of particles in the area (0.045 to $0.13 \mathrm{~d}^{-1}$, Sempéré et al. 2000). These values are also in the same order of magnitude as the lower range of the turnover rate $\left(0.03 \mathrm{~d}^{-1}\right)$ of a glucosylated protein (Keil \& Kirchman 1999) assumed to represent a pool of 'limited bioreactivity'. In order to explore the best probable estimates of hydrolysis fluxes, we additionally computed hydrolysis of detrital POC by using a constant value for the hydrolysis rate $\left(0.13 \mathrm{~d}^{-1}\right)$ which corresponded to the higher value cited for the semi-labile pool (Keil \& Kirchman 1999, Sempéré et al. 2000). By applying both these constants (our Hr measured with MCA-leu and $0.13 \mathrm{~d}^{-1}$ ) to non-living POC, we assumed this pool as 'semi-reactive'. Note that accordingly, the ultralabile pool was considered separately.

Both thymidine conversion factors and hydrolysis turnover rates influenced the carbon budget. We computed the 2 extremes: (1) BCD at a maximum with the higher thymidine conversion factor and $\mathrm{PH}$ at a minimum with the lower hydrolysis turnover rate, (2) BCD at a minimum with the lower thymidine conversion factor and $\mathrm{PH}$ at a maximum with the higher hydrolysis

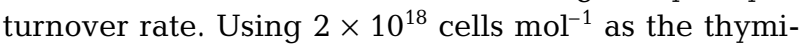
dine conversion factor for bacterial production and using $\mathrm{Hr}$ computed from our MCA-hydrolysis rates, the potential hydrolysis of non-living POC (PH) was always lower than the $\mathrm{BCD}$. The $\mathrm{PH} / \mathrm{BCD}$ ratio ranged from 7 to $30 \%$. PH/BCD ratio increased from 11 to $18 \%$ 
in surface layers, and decreased from 30 to $7 \%$ in the chlorophyll peak. Assuming that the ultralabile pool fueled $40 \%$ of the $\mathrm{BCD}$, the percentage of $\mathrm{BCD}$ coming from bulk DOC utilization amounted to $100 \%-40 \%-$ $(7$ to $30 \%)=30$ to $53 \%$. Thus in these cases bacteria also used the bulk DOC pool.

Using $0.8 \times 10^{18} \mathrm{cell} \mathrm{mol}^{-1}$ as the thymidine conversion factor for bacterial production and using $0.13 \mathrm{~d}^{-1}$ as hydrolysis turnover rates, the $\mathrm{PH} / \mathrm{BCD}$ ratio increased from 105 to $135 \%$ in surface layers, and decreased from 106 to $69 \%$ in the chlorophyll peak. Thus, in that case, in both layers the BCD is satisfied by both hydrolysis of the detrital pool and ultralabile pools, and some excess release is attained. This excess solubilization, calculated as $\mathrm{PH}-[\mathrm{BCD} \times(100 \%-$ $40 \%$ )] would range from 0.07 to $0.7 \mu \mathrm{M} \mathrm{C} \mathrm{d}^{-1}$. These fluxes are consistent with the spring-summer accumulation of DOC in the surface layers (15 to $25 \mu \mathrm{M}$, Copin-Montégut \& Avril 1993).

In both extreme cases studied, the changes in the way these different sources were shared evolved during the month and also differed between the 2 depths studied. The percentage coming from detrital POC hydrolysis increased in the surface layer and decreased in the chlorophyll peak. If the BGE constant was set at another value, this would not modify the tendencies over the month, but would just decrease (or increase) relatively the contribution of detritus hydrolysis to BCD and increase (or decrease) that of bulk DOC. However, the assumption that BGE is constant on a short time scale is not necessarily true (Middelboe \& Søndergaard 1993, Zweifel et al. 1993), and it is also probable that the modifying trophic status over the month would also change the participation of ultralabile DOC to BCD. Nevertheless, the tendencies that we observed by examining how different sources used by bacteria are shared is consistent with the hypothesis that we made from variations in the lipolysis index, $\mathrm{C}$-DL/DOC and TGd/DOC ratios in particulate and dissolved fractions.

In the water column, the surface layer and chlorophyll peak appeared as independent zones in which bacteria adapted differently during transition to preoligotrophic conditions. In most cases more than half of the POC was in a non-living form. An examination of carbon budgets revealed that potential sources issued from POC hydrolysis are not negligible, and to some extent release of DOC from detritus could occur. The relative share of bulk DOC and detrital POC as carbon resources for bacteria could vary on a monthly scale. The most striking feature was that in the chlorophyll maximum, the potential availability of detrital POC sources decreased whereas it increased in the surface layer. We demonstrated that combining the approaches used herein with correct conversion factors for BP, BGE and appropriate markers to estimate polymers hydrolysis could help in determining the origin of food resources for heterotrophic bacteria, and the fate and turnover of detrital POC on short time scales.

Acknowledgements. This work was supported by CNRSINSU, Opération DYFAMED-DYNAPROC (JGOFS-France) and the European program CANIGO-MAST3-CT96-0060. We are grateful to our cruise and project leader V. Andersen. We thank L. Prieur, H. Claustre, J.-C. Marty and anonymous reviewers for useful discussions and comments that helped to improve this manuscript.

\section{LITERATURE CITED}

Andersen V, Prieur L (2000) One-month study in the open NW Mediterranean Sea (DYNAPROC experiment, May 1995): overview of hydrobiogeochemical structures and effects of wind events. Deep-Sea Res I 47:397-422

Benner R, Pakulski DJ, Matthew M, Hedges JI, Hatcher PG (1992) Bulk chemical characteristics of dissolved organic matter in the ocean. Science 55:1561-1564

Bligh EG, Dyer WJ (1959) A rapid method of total lipid extraction and purification. Can J Biochem Physiol 37:911-917

Bochdansky AB, Puskaric S, Herndl GJ (1995) Influence of zooplankton grazing on free dissolved enzymes in the sea. Mar Ecol Prog Ser 121:53-63

Børsheim KY, Bratbak G (1987) Cell volume to cell carbon conversion factors for a bacterivorous Monas sp. enriched from seawater. Mar Ecol Prog Ser 36:171-175

Buck KR, Chavez FP, Campbell L (1996) Basin-wide distribution of living carbon components and the inverted trophic pyramid of the central gyre of the North Atlantic Ocean, summer 1993. Aquat Microb Ecol 10:283-298

Campbell L, Nolla HA, Vaulot D (1994) The importance of Prochlorococcus to community structure in the central North Pacific Ocean. Limnol Oceanogr 39:954-961

Carlson CA, Ducklow HW (1995) Dissolved organic carbon in the upper ocean of the central equatorial Pacific Ocean, 1992: daily and finescale vertical variations. Deep-Sea Res 42:639-656

Carlson CA, Ducklow HW (1996) Growth of bacterioplankton and consumption of dissolved organic carbon in the Sargasso Sea. Aquat Microb Ecol 10:69-85

Carlucci AF, Craven DB, Henrichs SM (1984) Diel production and microheterotrophic utilization of dissolved free amino acids in waters off southern California. Appl Environ Microbiol 48:165-170

Cauwet G, Miller A, Brasse S, Fengler G, Mantoura RFC, Spitzy A (1997) Dissolved and particulate organic carbon in the western Mediterranean Sea. Deep-Sea Res 44:769-779

Cherrier J, Bauer JE, Druffel ER (1996) Utilization and turnover of labile dissolved organic matter by bacterial heterotrophs in eastern North Pacific surface waters. Mar Ecol Prog Ser 139:267-279

Cho BC, Azam F (1990) Biogeochemical significance of bacterial biomass in the ocean's euphotic zone. Mar Ecol Prog Ser 63:253-259

Christaki U, Van Wambeke F (1995) Simulated phytoplankton bloom input in top-down manipulated microcosms: comparative effect of zooflagellates, ciliates and copepods. Aquat Microb Ecol 9:137-147

Christaki U, Van Wambeke F, Christou ED, Conan P, Gaudy R 
(1996) Food web structure variability in the surface layer, at a fixed station influenced by the Northwestern Mediterranean Current. Hydrobiologia 321:145-153

Chrost RJ (1991) Ectoenzymes in aquatic environments: microbial strategy for substrate supply. Verh Int Verein Limnol 24:2597-2600

Chung SC, Gardner WD, Landry MR, Richardson MJ, Walsh ID (1998) Beam attenuation by microorganisms and detrital particles in the equatorial Pacific. J Geophys Res 103: 12669-12681

Claustre H, Gostan J (1987) Adaptation of biochemical composition and cell size to irradiance in two microalgae: possible ecological implications. Mar Ecol Prog Ser 40: 167-174

Claustre H, Kerhervé P, Marty JC, Prieur L, Videau C, Hecq JH (1994) Phytoplankton dynamics associated with a geostrophic front: ecological and biogeochemical implications. J Mar Res 52:711-742

Claustre H, Morel A, Babin M, Caillau C, Marie D, Marty JC, Taillez D, Vaulot D (1999) Variability in particle attenuation and chlorophyll fluorescence in the tropical Pacific: scales, patterns, and biochemical implications. J Geophys Res 104:3401-3422

Coffin RB, Connolly JP, Harris PS (1993) Availability of dissolved organic carbon to bacterioplankton examined by oxygen utilization. Mar Ecol Prog Ser 9:9-22

Copin-Montégut G, Avril B (1993) Vertical distribution and temporal variation of dissolved organic carbon in the northwestern Mediterranean Sea. Deep-Sea Res 40: 1963-1972

Crottereau C, Delmas D (1998) Exoproteolytic activity in an Atlantic pond (France): estimates of in situ activity. Aquat Microb Ecol 15:217-224

Cullen JJ (1982) The deep chlorophyll maximum: comparing profiles of chlorophyll a. Can J Fish Aquat Sci 39: 791-803

Dafner E, Sempéré R, Gonzalez N, Gomez F, Goutx M (1999) Cross-slope variations of dissolved organic carbon in the Gulf of Cadix, NE Atlantic Ocean (February 1998). Mar Ecol Prog Ser 189:301-306

del Giorgio PA, Cole JJ (1998) Bacterial growth efficiency in natural aquatic systems. Annu Rev Ecol Syst 29:503-541

Ducklow HW, Carlson CA (1992) Oceanic bacterial production. In: Marshall KC (ed) Advances in microbial ecology. Plenum Press, New York, p 113-181

Durbin EG (1977) Studies on the autoecology of the marine diatom Thalassiosira nordenskioeldii. II The influence of cell size on growth rate, and carbon, nitrogen, chlorophyll a and silica content. J Phycol 13:150-155

Fernández M, Bianchi M, Van Wambeke F (1994) Bacterial biomass, heterotrophic production and utilization of dissolved organic matter photosynthetically produced in the Almeria-Oran front. J Mar Syst 5:313-325

Fuhrman JA, Azam F (1982) Thymidine incorporation as a measure of heterotrophic production in marine surface waters. Evaluation and field results. Mar Biol 66:109-120

Gasol JM, Doval MD, Pinhassi J, Calderon-Paz JI, GuixaBoixareu N, Vaqué D, Pedros-Alio C (1998) Diel variations in bacterial heterotrophic activity and growth in the northwestern Mediterranean Sea. Mar Ecol Prog Ser 164: 107-124

Geider RJ, MacIntyre HL, Kana TM (1997) Dynamic model of phytoplankton growth and acclimation: responses of the balanced growth rate and the chlorophyll a:carbon ratio to light, nutrient limitation and temperature. Mar Ecol Prog Ser 148:187-200

Gonzalez JM, Torréton JP, Dufour, P, Charpy L (1998) Tempo- ral and spatial dynamics of the pelagic microbial food web in an atoll lagoon. Aquat Microb Ecol 16:53-64

Goutx M, Gérin C, Bertrand JC (1990) An application of Iatroscan thin-layer chromatography with flame ionization detection-lipid classes of microorganisms as biomarkers in the marine environment. Org Geochem 16: 1231-1237

Goutx M, Momzikoff A, Striby L, Marty JC,Vescovali I (2000) High frequency fluxes of labile compounds in the central Ligurian Sea, northwestern Mediterranean. Deep-Sea Res I 47:533-556

Hagström ̊̊, Ammermann JW, Henrichs S, Azam F (1984) Bacterioplankton growth in sea water: II. Organic matter utilization during steady state growth in sea water cultures. Mar Ecol Prog Ser 18:41-48

Halemejko GZ, Chrost RJ (1986) Enzymatic hydrolysis of proteinaceous particulate and dissolved material in an eutrophic lake. Arch Hydrobiol Limnol 107:1-21

Hoppe H, Kim S, Gocke K (1988) Microbial decomposition in aquatic environments: combined process of extracellular enzyme activity and substrate uptake. Appl Environ Microbiol 54:784-790

Hoppe H, Ducklow H, Karrasch B (1993) Evidence for dependency of bacterial growth on enzymatic hydrolysis of particulate organic matter in the mesopelagic ocean. Mar Ecol Prog Ser 93:277-283

Jahnke RA, Craven DB (1995) Quantifying the role of heterotrophic bacteria in the carbon cycle: a need for respiration rate measurements. Limnol Oceanogr 40:436-441

Jørgensen NOG (1987) Free amino acids in lakes: concentrations and assimilation rates in relation to phytoplankton and bacterial production. Limnol Oceanogr 32:97-111

Jørgensen NOG, Kroer N, Coffin RB, Hoch MP (1999) Relations between bacterial nitrogen metabolism and growth efficiency in an estuarine and an open-water ecosystem. Aquat Microb Ecol 18:247-261

Jumars PA, Penry DL, Baross JA, Perry MA, Frost BW (1989) Closing the microbial loop: dissolved carbon pathway to heterotrophic bacteria from incomplete ingestion, digestion and absorption in animals. Deep-Sea Res 36:483-495

Kana T, Glibert PM (1987) Effect of irradiances up to $2000 \mu \mathrm{E}$ $\mathrm{m}^{-2} \mathrm{~s}^{-1}$ on marine Synechoccus WH 7803-I. Growth, pigmentation and cell composition. Deep-Sea Res 34:479-516

Karner M, Rassoulzadegan F (1995) Extracellular enzyme activity: indications for high short-term variability in a coastal marine ecosystem. Microb Ecol 30:143-156

Kepkay PE, Johnson BD (1988) Microbial response to organic particle generation by surface coagulation in seawater. Mar Ecol Prog Ser 48:193-198

Kepkay PE, Wells ML (1992) Dissolved organic carbon in North Atlantic surface waters. Mar Ecol Prog Ser 80: 275-283

Kiel RG, Kirchman DL (1999) Utilization of dissolved protein and amino acids in the northern Sargasso Sea. Aquat Microb Ecol 18:293-300

Lamy F, Bianchi M, Van Wambeke F, Sempéré R, Talbot V (1999) Use of data assimilation techniques to analyze the significance of ectoproteolytic activity measurements performed with the model substrate MCA-leu. Mar Ecol Prog Ser 177:27-35

Lee S, Fuhrman JA (1987) Relationships between biovolume and biomass of naturally derived marine bacterioplankton. Appl Environ Microbiol 53:1298-1303

Li WKW, Dickie PM, Irwin BD, Wood AM (1992) Biomass of bacteria, cyanobacteria, prochlorophytes and photosynthetic eukaryotes in the Sargasso Sea. Deep-Sea Res 39: $501-519$ 
Martin V (1997) Etude par cytométrie en flux de la distribution des populations phytoplanctoniques en Méditerranée. Mise en relation avec la production métabolique de $\mathrm{CO}_{2}$ et comparaison avec le Golfe du Saint-Laurent. Doctorat Université de la Méditerranée, France, p 212

Marty JC, Nicolas E, Miquel JC, Fowler SW (1994) Particulate fluxes of organic compounds and their relationship to zooplankton fecal pellets in the northwestern Mediterranean Sea. Mar Chem 46:387-405

McCarthy M, Hedges J, Benner R (1996) Major biochemical composition of dissolved high molecular weight organic matter in seawater. Mar Chem 55:281-297

Middelboe M, Søndergaard M (1993) Bacterioplankton growth yield: seasonal variations and coupling to substrate lability and ß-glucosidase activity. Appl Environ Microbiol 59:3916-3921

Middelboe M, Søndergaard M, Letarte Y, Borch NH (1995) Attached and free-living bacteria: production and polymer hydrolysis during a diatom bloom. Microb Ecol 29: 231-248

Miquel JC, Fowler SW, La Rosa J, Buat-Menard P (1994) Dynamics of the downward flux of particles and carbon in the open northwestern Mediterranean Sea. Deep-Sea Res 41:243-261

Mostajir B, Dolan J, Rassoulzadegan F (1995) A simple method for the quantification of a class of labile marine pico-and nano-sized detritus: DAPI Yellow Particles (DYP). Aquat Microb Ecol 9:259-266

Norland S (1993) The relationship between biomass and volume of bacteria. In: Kemp PF, Sherr BF, Sherr EB, Cole JJ (eds) Handbook of methods in aquatic microbial ecology. Lewis Publishers, Boca Raton, p 303-307

Passow U, Alldredge AL (1994) Distribution, size and bacterial colonization of transparent exopolymer particles (TEP) in the ocean. Mar Ecol Prog Ser 113:185-198

Pedros-Alio C, Calderon-Paz JI, Guixa-Boixereu N, Estrada M, Gasol JM (1999) Bacterioplankton and phytoplankton biomass and production during summer stratification in the northwestern Mediterranean Sea. Deep-Sea Res I 46: 985-1019

Pérez MT, Dolan JR, Vidussi F, Fukai E (2000) Diel vertical distribution of planktonic ciliates within the surface layer of the NW Mediterranean (May 1995). Deep-Sea Res I 47 : 479-503

Sempéré R, Van Wambeke F, Arzoumanian H, Ferrière L, Bianchi M (1998) On the use of batch systems to determine DOC bacterial lability and bacterial growth efficiency in seawater samples. In: Dehairs F, Elskens M, Goeyens L (eds) Integrated marine system analysis. Proceedings of the second network meeting (Brussels, May 29-31, 1997). VUB, Brussels, p 223-238

Sempéré R, Yoro SC, Van Wambeke F, Charriere B (2000) Microbial decomposition of large organic particles in northwestern Mediterranean Sea. Mar Ecol Prog Ser 198: 61-72

Simon M, Alldredge AL, Azam F (1990) Bacterial carbon dynamics on marine snow. Mar Ecol Prog Ser 65:205-211

Editorial responsibility: Otto Kinne (Editor), Oldendorf/Luhe, Germany
Skoog A, Biddanda B, Benner R (1999) Bacterial utilization of dissolved glucose in the upper water column of the Gulf of Mexico. Limnol Oceanogr 44:1625-1633

Smith DC, Simon M, Alldredge AL, Azam F (1992) Intense hydrolytic activity on marine aggregates and implications for rapid particle dissolution. Nature 359:139-142

Stemmann L, Picheral M, Gorsky G (2000) Diel variation in the vertical distribution of particulate matter $(>0.15 \mathrm{~mm})$ in the NW Mediterranean Sea investigated with the Underwater Video Profiler. Deep-Sea Res I 47:505-531

Striby L (2000) Biogéochimie de la matière organique marine dans 2 écosystèmes marins. Cas d'une structure physique unidimensionnelle verticale (Mer Ligure) et d'une structure physique frontale (Front Alméria-Oran). Variations spatio-temporelles de la fraction lipidique à petite échelle. Doctorat de Sciences de l'Environnement Marin, Aix-Marseille II

Striby L, Lafont R, Goutx M (1999) Improvement in the Iatroscan thin-layer chromatography-flame ionisation detection analysis of marine lipids. Separation and quantitation of mono- and diacylglycerols in standards and natural samples. J Chromatogr A 849:371-380

Taylor AH, Geider RJ, Gilbert FJ (1997) Seasonal and latitudinal dependancies of phytoplankton carbon-to-chlorophyll a ratios: results of a modelling study. Mar Ecol Prog Ser 152:51-66

Van Wambeke F (1995) Numération et taille des bactéries planctoniques au moyen de l'analyse d'images couplée à l'épifluorescence. Oceanis 21:113-124

Van Wambeke F, Christaki U, Gaudy R (1996) Carbon fluxes from the microbial food web to mesozooplankton. An approach in the surface layer of a pelagic area (NW Mediterranean Sea). Oceanol Acta 19:57-66

Vidussi F (1998) Variabilité spatiale et temporelle des marqueurs pigmentaires des communautés autotrophes en Méditerranée: implications biogéochimiques. Thèse de Doctorat de l'Université Paris VI, Océanologie Biologique et Environnement Marin

Vidussi F, Marty JC, Chiaverini J (2000) Phytoplankton pigment variations during the transition from spring bloom to oligotrophy in the northwestern Mediterranean Sea. Deep-Sea Res I 47:423-445

Yoro SC, Sempéré R, Turley CM, Unanue MA, Durieu De Madron X, Bianchi M (1997) Cross-slope variations of organic carbon and bacteria in the Gulf of Lions in relation to water dynamics (northwestern Mediterranean). Mar Ecol Prog Ser 161:255-264

Yoro SC, Panagiotopoulos C, Sempéré R (1999) Dissolved organic carbon contamination induced by filters and storage bottles. Water Res 33:1956-1959

Zohary T, Robarts RD (1992) Bacterial numbers, bacterial production, and heterotrophic nanoplankton abundance in a warm core eddy in the Eastern Mediterranean. Mar Ecol Prog Ser 84:133-137

Zweifel U, Norrman B, Hagström Å (1993) Consumption of dissolved organic carbon by marine bacteria and demand for inorganic nutrients. Mar Ecol Prog Ser 101:23-32

Submitted: February 11, 2000; Accepted: June 29, 2000

Proofs received from author(s): February 8, 2001 